\title{
INDEX OF ANALYSES OF NATURAL WATERS IN THE UNITED STATES
}

\author{
By W. D. Collins and C. S. Howard
}

\section{INTRODUCTION}

Examinations of water by Federal, State, or municipal agencies have been made mainly for the solution of problems relating to health and sanitation, but many analyses have been made that show the chemical characteristics of waters and indicate their suitability for industrial use and for irrigation.

The water-supply papers and other publications of the United States Geological Survey contain more mineral analyses than any other series of publications. Several State laboratories have published collections of mineral analyses and either alone or in cooperation with the United States Geological Survey have made comprehensive surveys of the surface and ground waters within their respective States. For other States comparatively little has been published. The list of published collections of analyses given in this paper is intended to include all Federal and State reports of geological surveys, experiment stations, and health departments. In addition, references are given to journal articles that contain collections of analyses. The Geological Survey will welcome corrections or additions for revision or extension of the list.

\section{ANALYSÉS FOR PRIVATE INTERESTS}

As a general rule public funds are not available to pay for making water analyses for the benefit of private persons or corporations. It is evident, however, that many analyses which may have value to individuals ought to be made for the public welfare. This consideration applies particularly to examinations of the sanitary condition of bottled water or water from privately owned systems of public water supply.

In areas that are not fully developed the analysis of water for private interests may be a useful part of governmental aid in the settlement and development of the lands, to add to the wealth and income of a State. In the course of a systematic survey of water conditions 
in an area many analyses of waters controlled by private persons are likely to be made, but the samples are taken as representative of conditions in definite geologic formations or in certain significant localities.

\section{ANALYSES FOR PUBLIC SURVEYS}

The individual who wishes to know the chemical composition of water from a particular source can have an analysis made by a commercial laboratory as well as by a public laboratory. The one who wishes to know where water of a given composition can be obtained or the sections of the country where different kinds of water are to be found can hardly afford to send and get samples for all the analyses needed to answer his question, much less to pay for the analyses. An inventory of the natural waters available throughout a State, part of a State, or a larger unit is of value to many individuals and is evidently work that must be handled by some public agency if it is to be done without needless duplication of effort.

In a survey of water conditions such as is given in certain United States Geological Survey water-supply papers a moderate number of analyses are so used as to have the value of a much greater number. Study of the analyses in relation to geologic conditions makes possible prediction of the probable quality of water in a well not yet drilled. Reports of a general character may have more value to persons not living in the area than they do to those who use the waters for which analyses are given.

A published analysis of water from a given source may save not only the expense of collection and analysis of a sample but also the time required to make an analysis, which may be a few days or a few weeks.

\section{PUBLISHED ANALYSES}

The list of published collections of analyses on pages 56-85 is confined almost wholly to reports containing several or many complete mineral analyses. Under "General reports" are given those which contain analyses of waters from more than one State. Under each State reference is made to general reports that contain analyses for the State, and the individual reports for the State are listed. The number of analyses in each report is indicated, at least approximately, and the analyses are classified by types of analyses and types of sources. In the list of publications the term "analysis" without qualification is used for analyses that include determinations of the mineral constituents generally present in significant quantities in natural waters. These analyses may not show the quantities of potassium; but they give the quantities of calcium, magnesium, chloride, sulphate, and alkalinity. Silica and either iron or iron and aluminum oxides together are generally given. Sodium is given or 
can be calculated. Nitrate is nearly always given for waters containing more than a few tenths of a part per million.

Partial analyses generally include determinations of total dissolved solids and of several constituents, but not enough to make it possible to calculate the sodium. An assay usually includes determinations of the acid radioles and hardness. Sanitary analyses include determinations of nitrogen in various forms, chloride, total dissolved solids, and sometimes iron and total hardness.

Reports containing only sanitary analyses have not been listed unless they record investigations of special importance or relate to areas for which few mineral analyses are available.

The most comprehensive studies of surface waters are reported in United States Geological Survey Water-Supply Papers 236, 237, 239, $273,274,339$, and 363 (general report 8, California 19, Illinois 13, Kansas 5, general report 10, Washington 4, Oregon 2). Most of the analyses in all these publications except Water-Supply Paper 274 are reprinted in Professional Paper 135 (general report 21). A number of the analyses of surface waters from these papers are also given in Bulletin 770 (general report 22).

Each of the water-supply papers mentioned above contains tables giving analyses of weekly composites or ten-day composites of daily samples of water taken over a period of a year. In addition a number of single analyses of surface waters are given in most of the reports.

Some of the reports containing analyses of mineral waters are listed below; for the larger reports the number of analyses is indicated in parentheses.

General reports: $1,3,4,7,11,14,22$.

Alabama: 1.

Alaska: 1.

Arkansas: 1, 2, 3.

California: 6 (100), 14 (41), 22 (300).

Colorado: 1, 3, 4, 8, 14, 15, 20, 21, 25 (202), 26.

Georgia: 3 (170).

Indiana: 3 (80).

Kansas: 2 (129).

Kentucky: 2, 3, 4, 5, 6, 9, 10.

Maine: 2, 4, 7.

Missouri: 1, 2, 3 (180).

New Mexico: 8.

New York: 4, 5.

North Carolina: 2.

\section{AVAILABILITY OF THE PUBLICATIONS LISTED}

Most of the publications listed are available for consultation in the larger public and educational libraries. Many are out of print, some can be purchased, and others are still available for free distribution from the office of publication. The price is given for Geological Sur- 
vey publications that are for sale. Geologic folios can be purchased only from the Director, United States Geological Survey, Washington, D. C.; all other Survey publications are sold by the Superintendent of Documents, Government Printing Office, Washington, D. C. Payment for publications is required in advance. Some of the Geological Survey publications are available for free distribution by the Survey during the first year after publication, but the supply available for free distribution is generally exhausted before the end of the year.

\section{PUBLICATIONS CONTAINING COLLECTIONS OF MINERAL ANALYSES OF WATERS}

[Figures in parentheses alone or followed by " $s$ " indicate number of analyses. For example, "(14s, 22)" means that the report contains 14 series of analyses of surface waters covering a period of about a year for each place, and 22 single analyses of either surface or ground water.]

\section{GENERAL REPORTS}

1. Peale, A. C., Lists and analyses of the mineral springs of the United States: U. S. Geol. Survey Bull. 32, 1886 (out of print). More than 850 analyses of spring waters are quoted from many sources.

2. Darton, N. H., Artesian-well prospects in the Atlantic Coastal Plain region: U. S. Geol. Survey Bull. 138, 1896 (out of print). Analyses of water from wells in Coastal Plain of Georgia (1), New Jersey (9), Maryland (2), and South Carolina (9).

3. Crook, J. K., Mineral waters of the United States and their therapeutic uses, New York and Philadelphia, Lea Brothers \& Co., 1899. More than 450 analyses of mineral waters made by many analysts. A number of the analyses are copied from advertising matter put out by the spring owners.

4. Fuller, M. L., Contributions to the hydrology of eastern United States: U. S. Geol. Survey Water-Supply Paper 102, 1904 (out of print). 111 sanitary analyses of waters from Vermont and 200 mineral analyses, of which 100 represent spring waters from Connecticut (38), Florida (17), Massachusetts (24), Michigan (26), Missouri (48), New Hampshire (20), New York (14), and other States (a few each).

5. Fuller, M. L., Contributions to the hydrology of eastern United States: U. S. Geol. Survey Water-Supply Paper 110, 1905 (out of print). Sanitary analyses of 40 samples from Watkins Glen quadrangle, New York, and 25 mineral analyses of samples from other States.

6. Jackson, D. D., The normal distribution of chlorine in the natural waters of New York and New England: U. S. Geol. Survey Water-Supply Paper 144, 1905 (10 cents). Determinations of chloride in unpolluted waters from Connecticut $(1,200)$, Maine (120), Massachusetts (6), New Hampshire (150), New York (100), Rhode Island (13), Vermont (100).

7. Haywood, J. K., and Smith, B. H., Mineral waters of the United States: U. S. Dept. Agr. Bur. Chemistry Bull. 91, 1905 (out of print). Analyses (by the authors) of 41 samples of bottled mineral waters purchased on the open market and of 13 samples from Saratoga Springs, N. Y., collected for the report, with advertised analyses for comparison. The methods of analysis used are described. The classification and the medicinal value of mineral waters are discussed. 
8. Dole, R. B., The quality of surface waters in the United States, Part I, Analyses of waters east of the one hundredth meridian: U. S. Geol. Survey Water-Supply Paper 236, 1909 (out of print). 71 tables of analyses (by chemists of the water-resources branch of the United States Geological Survey) of composites of samples of surface waters taken daily for a year or longer. The methods of analysis used are described and the accuracy of the results discussed. The tables of analyses are reprinted in general report 21.

9. Palmer, Chase, The geochemical interpretation of water analyses: U. S. Geol. Survey Bull. 479, 1911 (out of print). Averages of 31 sets of analyses of surface waters from general report 8 and a few analyses from other sources are classified and discussed in terms of the properties of reaction introduced by the author in this report. The method of recording and interpreting analyses first used in this paper has been followed in a number of later reports, particularly those relating to oil-field waters.

10. Stabler, Herman, Some stream waters of the western United States, with chapters on sediment carried by the Rio Grande and the industrial application of water analyses: U. S. Geol. Survey Water-Supply Paper 274, 1911 (out of print). Analyses of composites of daily samples of surface waters are given in 55 tables. Partial analyses (acid radicles and total dissolved solids) of weekly composites of daily samples of surface waters are given in $\mathbf{5 4}$ tables. The paper contains 80 analyses of single samples from streams and 120 analyses of samples from wells. The analyses were made by C. H. Stone and other chemists of the United States Reclamation Service. The section on the industrial application of water analyses gives Stabler's formulas and classification of waters for industrial use and for irrigation, which have been followed in many later publications.

11. Skinner, W. W., and Stiles G. W., jr., American mineral waters-the New England States: U. S. Dept. Agr. Bur. Chemistry Bull. 139, 1911 (out of print). Chemical and bacteriologic analyses of 38 spring waters from New England, made in the Bureau of Chemistry.

12. Emmons, W. H., The enrichment of sulphide ores: U. S. Geol. Survey Bull. 529, 1913 (out of print). 13 analyses of waters from copper mines and 19 analyses of waters from gold and silver mines. Most of these analyses are also given in general report 16.

13. Phalen, W. C., The occurrence of potash salts in the bitterns of the eastern United States: U. S. Geol. Survey Bull. 530, pp. 313-329, 1913 (out of print; also in Bull. 530-B, 5 cents). Analyses (from miscellaneous sources) of bitterns from Michigan (8), New York (6), Ohio (5), and West Virginia (2).

14 Clarke, F. W., Water analyses from the laboratory of the United States Geological Survey: U. S. Geol. Survey Water-Supply Paper 364, 1914 (5 cents). "203 analyses made in the chemical laboratory of the United States Geological Survey. Most of them have been published elsewhere, but many of the original documents are out of print and therefore obtainable with difficulty." Includes all analyses from Geological Survey Bulletins 9, 27, 42, 47, 60, 64, and 113.

15. Siebenthal, C. E., Origin of the zinc and lead deposits of the Joplin region, Missouri,Kansas, and Oklahoma: U. S. Geol. Survey Bull. 606, 1915 (out of print). 119 analyses (from miscellaneous sources) of zinc-bearing and related waters. 
16. Emmons, W. H., The enrichment of ore deposits: U. S. Geol. Survey Bull. 625,1917 (out of print). Analyses of 56 mine waters, of which 37 are published in general report 12. Graphs based on analyses of 117 waters from hot springs.

17. Phalen, W. C., Technology of salt making in the United States: U. S. Bur. Mines Bull. 146, 1917 (25 cents). 14 analyses of brines made by W. B. Hicks, of the United States Geological Survey, for this report, to supplement data in general report 18, and 21 other analyses of brines and bitterns.

18. Phalen, W. C., Salt resources of the United States: U. S. Geol. Survey Bull. 669, 1919 (35 cents). 254 analyses of natural and artificial brines and of bitterns from brines and from sea water. Most of the analyses were made by chemists of the United States Geological Survey and of the Bureau of Soils of the Department of Agriculture. Includes 175 analyses of brines published in Bur. Soils Bull. 94, 1913, The occurrence of potassium salts in the salines of the United States, by J. W. Turrentine and others. About 100 of the analyses are published in a series of articles entitled" "Composition of the salines of the United States, by J. W. Turrentine, with analyses by A. R. Merz and R. F. Gardiner (pt. 1, Rock salt, artificial brines and mother liquors from artificial brines: Jour. Ind. and Eng. Chemistry, vol. 4, p. 828, 1912; pt. 2, Natural (subterranean) brines and mother liquors from natural brines: Idem, p. 885; pt, 3, Brines from the ocean and salt lakes: Idem, vol. 5, p. 19, 1913).

19. Mills, R. V. A., and Wells, R. C., The evaporation and concentration of waters associated with petroleum and natural gas: U. S. Geol. Survey Bull. 693, 1919 (20 cents). 39 analyses of brines from Appalachian oil and gas fields and 15 partial analyses of waters from shallow wells in the area. Some of the analyses were made in the United States Geological Survey.

20. Collins, W. D., The industrial utility of public water supplies in the United States: U. S. Geol. Survey Water-Supply Paper 496, 1923. (10 cents). Analyses (from miscellaneous sources) showing the chemical character of water from public supplies of $\mathbf{3 0 7}$ larger cities.

21. Clarke; F. W., The composition of the river and lake waters of the United States: U. S. Geol. Survey Prof. Paper 135, 1924 (50 cents). 193 tables of analyses of 10-day composites of daily samples for about a year, from Water-Supply Papers 236, 237, 239, 273, 339, 363 (general report 8, California 19, Illinois 13, Kansas 5, Oregon 2, Washington 4). Nearly 800 single analyses of surface waters from all parts of the United States. About one-third have not been published before.

22. Clarke, F. W., The data of geochemistry, 5th edition: U. S. Geol. Survey Bull. 770, 1925 ( $\$ 1$ ). Over 200 analyses of surface waters and over 100 analyses of waters from wells and springs. Many of the surfacewater analyses are averages of series of analyses reprinted in general report 21. References are given to publications containing more extensive collections of analyses of certain types or from special places. The earlier editions of "The data of geochemistry" were U. S. Geological Survey Bulletins 330, 491, 616, 695. A few additions or omissions of water analyses were made at each revision, but the analyses are substantially the same in all the editions. 


\section{ALABAMA}

General reports: 1 (19), $3(9), 4(2), 8(3 \mathrm{~s}), 20(5), 21$ (3 s, 1), 22 (3).

1. Smith, E. W., The underground water resources of Alabama, Alabama Geol. Survey, 1907. 110 analyses (made for the report) of well and spring waters. The report deals mainly with mineral waters.

\section{ALASKA}

General reports: $21(1 \mathrm{~s}, 31), 22(8)$.

1. Waring, G. A., Mineral springs of Alaska, with a chapter on the chemical character of some surface waters of Alaska by R. B. Dole and A. A. Chambers: U. S. Geol. Survey Water-Supply Paper 418, 1917 (25 cents). Analyses of spring waters (29) and Yukon River (17) made by the United States Geological Survey. Analyses of streams in Yukon-Tanana region (11) and other surface waters (8) made for the report by S. C. Dinsmore.

\section{ARIZONA}

General reports: $1(3), 3(3), 10(4 s), 20(4), 21(5), 22(3)$.

1. Waters and water analyses: Arizona Agr. Exper. Sta. Bull. 4, 1891. Analyses (made at Experiment Station) of water from 3 wells and 13 surface supplies. Contains directions for sampling water for analysis.

2. Collingwood, C. B., Soils and waters: Arizona Agr. Exper. Sta. Bull. 6, 1892. Monthly analyses of the sediment from samples of Colorado River water taken daily for seven months.

3. McClatchie, A. J., and Forbes, R. H., Sugar-beet experiments during 1898: Arizona Agr. Exper. Sta. Bull. 30, 1899. Discussion of water supply for factory requirements. Analyses (made at Experiment Station) of 36 samples of well water from Salt River Valley, with a discussion of the suitability of their use in the manufacture of beet sugar.

4. Arizona Agr. Exper. Sta. Eleventh Ann. Rept., for year ending June 30, 1900 (report of the Dept. of Chemistry, pp. 180-184). Partial analyses (made at Experiment Station) of water from Colorado River at Yuma, Gila River at Florence, Salt River at Mesa City, and of samples from nine wells.

5. Forbes, R. H., The river irrigating waters of Arizona, their character and effects: Arizona Agr. Exper. Sta. Bull. 44, 1902. Analyses (made at Experiment Station) of irrigating waters of the Territory: Gila River (6), Salt River (7), Colorado (7), miscellaneous sources (16 partial).

6. Skinner, W. W., The underground waters of Arizona, their chemistry and uses: Arizona Agr. Exper. Sta. Bull. 46, 1903. 300 analyses (made at Experiment Station) of waters from various sources throughout the territory.

7. Lee, W. T., The underground waters of Gila Valley, Ariz.: U. S. Geol. Survey Water-Supply Paper 104, 1904 (10 cents). 23 analyses from miscellaneous sources.

8. Lee, W.T., Underground waters of Salt River valley, Ariz.: U. S. Geol. Survey Water-Supply Paper 136, 1905 (25 cents). Analyses from Experiment Station Bulletins 30 (36), 44 (6), and 46 (125) (Arizona 3, 5, 6). 9 analyses of underflow of Salt and Gila rivers.

9. Arizona Agr. Exper. Sta. Twenty-third Ann. Rept., for year ending June 30, 1912, pp. 698-700. Observations of the close proximity of black alkaline and calcium sulphate waters. Partial analyses (made at Experiment Station) of 7 well waters and 1 surface water. Discussion of the neutralizing effect of black alkali and gypsum. 
10. Meinzer, O. E., and Kelton, F. C., Geology and water resources of Sulphur Spring Valley, Ariz.: U. S. Geol. Survey Water-Supply Paper 320, 1913 (45 cents). 123 partial analyses (by W. H. Ross, Arizona Agr. Exper. Sta.) of ground water of the area.

11. Meinzer, O. E., and Ellis, A. J., Ground water in Paradise Valley, Ariz.: U. S. Geol. Survey Water-Supply Paper 375, pp. 51-75, 1916 (out of print). 10 assays of waters from wells, made for the report by A. E. Vinson, Arizona Agr. Exper. Sta.

12. Schwennesen, A. T., Ground water in San Simon Valley, Arizona and New Mexico: U. S. Geol. Survey Water-Supply Paper 425, pp. 1-35, 1919 (out of print). 14 analyses of waters from wells and springs, made by A. E. Vinson and D. W. Moore, Arizona Agr. Exper. Sta.

13. Arizona Agr. Exper. Sta. Ann. Rept. for 1919. 11 complete analyses of water from Salton Sea, made from 1907 to 1918. Each of the annual reports from 1908 to 1914 and 1916 contains the analyses completed when it was published.

14. Vinson, A. E., Catlin, C. N., and Griffin, S. W., Studies of irrigated soils and irrigation waters: Arizona Agr. Exper. Sta. Thirty-first Ann. Rept., for year ending June 30, 1920, pp. 436-439. Partial analyses (made at Experiment Station) of 5 monthly samples of water from the Tempe drainage ditch. Data on the character of the ground waters east of Agua Fria River.

15. Ross, C. P., The lower Gila region, Ariz: U. S. Geol. Survey Water-Supply Paper 498, 1923 (50 cents). 29 analyses (mostly by United States Geological Survey) of samples from watering places.

16. Bryan, Kirk, The Papago country, Ariz: U. S. Geol. Survey Water-Supply Paper 499 (in press; probably $\$ 1$ ). 32 analyses by A. A. Chambers and C. H. Kidwell, of the United States Geological Survey.

\section{ARKANSAS}

General reponts: 1 (5), 3 (3), 4 (3), 8 (2 s), 14 (5), $15(2), 21(1 \mathrm{~s}, 2), 22$ (2).

1. Arkansas Geol. Survey, vol. 1, 1891, The mineral waters of Arkansas. 9 analyses of spring waters from Hot Springs and 60 analyses of other mineral waters of the State.

2. Haywood, J. K., and Weed, W. H., The Hot Springs of Arkansas: 57th Cong., 1st sess., S. Doc. 282, 1902 (out of print). 46 analyses (by J. K. Haywood, U. S. Dept. Agr. Bur. Chemistry), of the waters of Hot Springs. Analyses reprinted in Arkansas 3.

3. Weed, W. H., Notes on certain hot springs of the southern United States: U. S. Geol. Survey Water-Supply Paper 145, pp. 185-206, 1905 (out of print). Analyses from Arkansas 2.

4. Veatch, A. C., Geology and underground water resources of northern Louisiana and southern Arkansas: U. S. Geol. Survey Prof. Paper 46, 1906 (out of print). Analyses of water from wells of Arkansas (10), Louisiana (22), Mississippi (1), and Texas (2).

5. Stephenson, L. W., and Crider, A. F., Geology and ground waters of northeastern Arkansas, with a discussion of the chemical character of the waters by R. B. Dole: U. S. Geol. Survey Water-Supply Paper 399, 1916 (out of print). 47 analyses of ground water by J. R. Bailey, Univ. Texas; 52 field assays by Stephenson and Crider. 


\section{California}

General reports 1 (44), $3(86), 7(1), 10(10 \mathrm{~s}), 12(2), 14$ (26), 18 (20), 20 (17), $21(33 \mathrm{~s}, 85), 22(20)$.

1. Hilgard, E. W., Alkali lands, irrigation and drainage in their mutual relations: California Univ. Agr. Exper. Sta. Rept. for 1886, appendix 7. 55 analyses (made at Experiment Station) of water from springs and wells.

2. Hilgard, E. W., Report of examination of waters, water supply, and related subjects: Advance sheets from combined reports of California College Agr. Exper. Stas. for 1888 and 1889 ; pp. 13-32, quantities of total solids for 42 samples of ground and surface waters; pp. 44-57, lake waters of San Joaquin Valley (also in Exper. Sta. Bull. 82, 1889), a study of the change in composition of the waters of Kern, Tulare, and Buena Vista lakes due to decrease in supply and evaporation; pp. 51-56, salts of the alkaline earths and alkalies, mutual reactions, discussion of this subject with respect to the change in Lake Tulare water.

3. Hilgard, E. W., California Agr. Exper. Sta. Rept. for 1890, pp. 51-82. Analyses (made at Experiment Station) of surface waters (9), springs (12), common wells (11), artesian wells (11).

4. Foster, E. Le N., Production of carbonate of soda from the alkaline waters of Owens Lake: Colorado Sci. Soc. Proc., vol. 3, p. 245, 1890. 4 analyses (from miscellaneous sources) of water from soda lakes with a discussion of the production of sodium carbonate.

5. Hilgard, E. W., Report of the Agricultural Experiment Stations of the University of California for the year 1891-92, pp. 50-75. Analyses (made at Experiment Station) of surface waters (13), springs (9), common wells (24), artesian wells (6).

6. Anderson, Winslow, Mineral springs and health resorts of California, San Francisco, Bancroft \& Co., 1892. Analyses (from miscellaneous sources) of about 100 California springs and about 200 other springs, American and foreign.

7. Hilgard, E. W., Report of the Agricultural Experiment Stations of the University of California for the year 1892-93 and part of 1894, pp. 157-184. Analyses (made at Experiment Stations) of surface waters (4), springs (10), common wells (32), artesian wells (9).

8. Lindgren, Waldemar, The gold-quartz veins of Nevada City and Grass Valley districts, Calif.; U. S. Geol. Survey Seventeenth Ann. Rept., pt. 2, p. 120, 1896 (out of print). 2 analyses of ground waters by W. F. Hillebrand.

9. Hilgard, E. W., Report of the Agricultural Experiment Stations of the University of California for the year 1897-98, pp. 118-130. Analyses (made at Experiment Stations) of surface waters (5), springs (16), common wells (38), artesian wells, reservoirs, and irrigation ditches (8).

10. Hilgard, E. W., Report of the Agricultural Experiment Stations of the University of California for the years 1898-1901, pt. 2, pp. 215-230. Analyses (made at Experiment Stations) of samples of surface waters (19), springs (67), common wells (155), artesian wells (19), reservoirs (24).

11. Lippincott, J. B., Development and application of water near San Bernardino, Colton, and Riverside, Calif.: U. S. Geol. Survey Water-Supply Paper 59, 1902 (out of print). Analyses of 1 surface water and 2 artesian wells.

12. Bailey, G. E., The saline deposits of California: California State Min. Bur. Bull. 24, 1902. About 15 analyses of brines of the State; most of them have been published elsewhere.

$50065^{\circ}-25-5$ 
13. Hamlin, Homer, Water resources of the Salinas Valley, Calif.: U. S. Geol. Survey Water-Supply Paper 89, 1904 (15 cents). Analysis of water from Arroyo Seco (1), San Lorenzo Creek in dry season (2) and in wet season (1). Made by Bureau of Soils, U. S. Dept. Agr.

14. Hilgard, E. W., Report of the Agricultural Experiment Station of the University of California for the year 1903-4, pp. 34-43. Analyses (made at Experiment Station) of water from streams (12), springs (41), common wells (82), artesian wells (9).

15. Lippincott, J. B., Water problems of Santa Barbara, Calif.: U. S. Geol. Survey Water-Supply Paper 116, 1905 (10 cents). Analyses (from miscellaneous sources) of water from Cold Spring Creek (1), Mission Creek (1), Mono Creek (8), Santa Ynez River (5), Santa Barbara City supply (1).

16. Mendenhall, W. C., The hydrology of San Bernardino Valley, Calif.: U. S. Geol. Survey Water-Supply Paper 142, 1905 (25 cents). Analyses (from miscellaneous sources) of surface water (1), springs (3), wells (4).

17. Lee, W. T., Geology and water resources of Owens Valley, Calif.: U. S. Geol. Survey Water-Supply Paper 181, 1906 (out of print). Four analyses of water of Owens Lake by Prof. Phillips, of England; Oscar Loew, of the Wheeler Survey; T. M. Chatard, of the U. S. Geological Survey; and C. H. Stone, of the U. S. Reclamation Service (1876-1905). Analysis of Mono Lake (1882) by T. M. Chatard.

18. Mitchell, J. P., A study of the normal constituents of the potable waters of the San Francisco Peninsula: Leland Stanford Junior Univ. Pub., Univ. Ser., Paper 1, 1910. Quantities of total solids, hardness, chloride, and nitrogen for about 240 ground and surface waters.

19. Van Winkle, Walton, and Eaton, F. M. The quality of the surface waters of California: U. S. Geol. Survey Water-Supply Paper 237, 1910 ( 20 cents ). 35 series of analyses covering about a year for the more important rivers. 35 single analyses of surface waters. Practically all analyses were made by or under the direction of the authors.

20. Johnson, H. R., Water resources of Antelope Valley, Calif.: U. S. Geol. Survey Water-Supply Paper 278, 1911 (out of print). 6 analyses of well and spring waters made by the United States Geological Survey.

21. Gale, H. S., Prospecting for potash in Death Valley, Calif.: U. S. Geol. Survey Bull. 540, pp. 407-415, 1914 (out of print). 14 partial and 4 complete analyses of brines from Death Valley made by the U. S. Geological Survey. Several potash determinations for waters of the area.

22. Hamilton, Fletcher, California State Mineralogist Fourteenth Bien. Rept. for 1913, California State Min. Bur., 1916. Analyses of spring water from Calaveras County (1), Humboldt County (2), Mendocino County (4), and foreign sources (3).

23. Waring, G. A., Springs of California: U. S. Geol. Survey Water-Supply Paper. 338,1915 (60 cents). About 300 analyses of spring waters. Many of the analyses were taken from California 6. Some were made by Oscar Loew, of the Wheeler Survey.

24. Mendenhall, W. C., Dole, R. B., and Stabler, Herman, Ground water in San Joaquin Valley, Calif.: U. S. Geol. Survey Water-Supply Paper 398, 1916 (25 cents). 400 field assays by R. B. Dole, U. S. Geological Survey, 50 analyses by F. M. Eaton, U. S. Geological Survey, and 65 analyses from miscella neous sources.

25. Hamilton, Fletcher, California State Mineralogist Fifteenth Bienn. R॰pt., for 1915-16, California State Min. Bur., 1919. 41 analyses of spring and lake waters. Most of them are from California 23 or other U.S. Geological Survey reports. 
26. McLaughlin, R. P., California State Oil and Gas Supervisor Second Ann. Rept. for 1916-1917: California State Min. Bur. Bull. 82, 1918. 10 analyses (from miscellaneous sources) of waters from the Casmalian field, p. 206. Total solids, total carbonate, total sulphate, and total chloride for waters from 13 wells of Petrol County, p. 335.

27. MeLaughlin, R. P., California State Oil and Gas Supervisor Third Ann. Rept., for 1917-1918: California State Min. Bur. Bull. 84, 1918. 15 analyses of "top waters" and 11 analyses of probable "bottom waters," p. 368. 3 analyses of "bottom waters" and 3 analyses of water from "water zone," p. 383. Analyses from miscellaneous sources.

28. Hicks, W. B., Evaporation of brine from Searles Lake, Calif.: U. S. Geol. Survey Prof. Paper 98, pp. 1-8, 1916 (out of print). 3 analyses of brine from the lake.

29. Rogers, G. S., Chemical relations of the oil-field waters in San Joaquin, Valley, Calif., U. S. Geol. Survey Bull. 653, 1917 (10 cents). 88 analyses of oil-field waters; 30 of the analyses were made by or for the U. S. Geological Survey.

30. Rogers, G. S., The Sunset-Midway oil field, Calif., Part II, Geochemical relations of the oil, gas, and water: U. S. Geol. Survey Prof. Paper 117, 1919 (out of print). Analyses of waters of this area made by the U. S. Geological Survey (29), by the Standard Oil Co. and the Kern Trading and Oil Co. (27), and by industrial chemists (18).

31. Waring, G. A., Ground water in the San Jacinto and Temecula basins, Calif.: U. S. Geol. Survey Water-Supply Paper 429, 1919 (40 cents). Analyses (40) and assays (70) of water from wells and springs; 4 analyses of surface waters. All made by S. C. Dinsmore.

32. Ellis, A. J., and Lee, C. H., Geology and ground waters of the western part of San Diego County, Calif.: U. S. Geol. Survey Water-Supply Paper 446 1919 (out of print). 7 analyses of surface waters and 9 assays of ground water, made in the water resources laboratory of the U. S. Geological Survey. 50 analyses of ground water made by S. C. Dinsmore.

33. Thompson, D. G., Ground water in Lanfair Valley, Calif. : U. S. Geol. Survey Water-Supply Paper 450, pp. 29-50, 1921 (40 cents). 4 analyses (3 made in water resources laboratory of U. S. Geological Survey).

34. Waring, G. A., Ground water in Pahrump, Mesquite, and Ivanpah valleys, Nev. and Calif.: U. S. Geol. Survey Water-Supply Paper 450, pp. 51-86, 1921 (Water-Supply Paper 450-C, 5 cents) (Nevada 11). Analyses (made for the report) of ground waters from California (12) and from Nevada (8).

35. Bryan, Kirk, Geology and ground water resources of Sacramento Valley, Calif.: U.S. Geol. Survey Water-Supply Paper 495, 1923 (60 cents). 47 analyses of ground water made by S. C. Dinsmore and 23 assays made by G. H. P. Lichthardt.

36. Brown, J. S., The Salton Sea region, Calif.: U. S. Geol. Survey Water-Supply Paper 497. 1923 (50 cents). 53 analyses of water of the Salton Sea region; 7 analyses of well waters of the Holtville area, Imperial Valley. Most of the analyses were made in the water-resources laboratory of the U.S. Geological Survey.

\section{COLORADO}

General reports: $1(38), 3(16), 7(1), 10(4 \mathrm{~s}), 12(5), 14(21), 15(11), 16(5)$, 20 (3), 21 (16), $22(8)$.

1. Smith, J. A., Report on the development of the mineral, metallurgical, agricultural, pastoral, and other resources of Colorado for the year 1881-82, Denver, Chain \& Hardy, 1883. Analyses of waters from hot sulphur springs. 
2. Chauvenet, Regis, Chemistry of the wells: Colorado Sci. Soc. Proc., vol. 1, sec. 3, 1884. 4 analyses of Denver artesian waters.

3. Chauvenet, Regis, Analyses of natural, thermal, and mineral waters of Colorado: Colorado School of Mines Bienn. Rept., p. 21, 1890. 15 analyses of waters from springs.

4. Lakes, Arthur, Hahns Peak: Colliery Eng. and Metal Miner, vol. 16, p. 147, 1895. Discusses the relation of mineral springs of Steamboat Springs to mineral deposits. Gives geology of the region and analyses of spring waters.

5. Emmons, S. F., Some mines of Rosita and Silver Cliff, Colo.: Am. Inst. Min. Eng. Trans., vol. 26, p. 773, 1896. 3 chemical analyses of waters from deep levels in Geyser mine; discussion of results.

6. Emmons, S. F., Cross, Whitman, and Eldridge, G. H., Geology of the Denver Basin in Colorado: U. S. Geol. Survey Mon. 27, 1896 (\$1.50). 4 analyses of well waters from Denver, published in Colorado 2, made by Prof. Regis Chauvenet, Colorado School of Mines, assisted by C. A. Gehrmann.

7. Gilbert, G. K., The underground water of the Arkansas Valley in eastern Colorado: U. S. Geol. Survey Seventeenth Ann. Rept., pt. 2, pp. 551-601, 1896 (out of print). 8 analyses (from miscellaneous sources) of underground waters.

8. Colorado State Bur. Mines Rept. for 1897. About 50 analyses of mineral springs of the State. Some analyses made by the U.S. Geological Survey; others from miscellaneous sources. Practically the same analyses are given in report for years 1901-2.

9. Strong, W. C., The sanitary chemical character of some of the artesian waters of Denver: Colorado Sci. Soc. Proc., vol. 5, p. 17, 1898. Discusses geologic occurrence of the waters and gives analyses.

10. Jones, L. J. W., Ferric sulphate in mine waters, its action on metals: Colorado Sci. Soc. Proc., vol. 6, p. 46, 1902. Describes experimental work and gives analyses of waters from mineral springs.

11. Headden, W. P., The ground water: Colorado Agr. Exper. Sta. Bull. 72, pt. 4, 1902. 14 analyses (made at Experiment Station) of ground water, with a discussion of the origin and effect of constituents.

12. Headden, W. P., Colorado irrigation waters and their changes: Colorado Agr. Exper. Sta. Bull. 82, 1903. Discussion of the character, source, and conditions affecting the nature of irrigation waters of Colorado. 50 analyses (made at Experiment Station) of surface and ground waters of the State. Some of the ground-water samples were taken to show change after irrigation.

13. Darton, N. H., Preliminary report on the geology and underground water resources of the central Great Plains: U. S. Geol. Survey Prof. Paper 32, 1905 (out of print). Analyses (from miscellaneous sources) of well waters. Colorado (11), Kansas (1), South Dakota (1), Wyoming (1).

14. Headden, W. P., The Doughty Springs, a group of radium-bearing springs, Delta County, Colo.: Am. Jour. Sci., 4th ser., vol. 19, p. 297, 1905. Describes the springs and gives 3 analyses. (Abstract from Colorado 15.)

15. Headden, W. P., The Doughty Springs, a group of radium-bearing springs on the north fork of the Gunnison River, Delta County, Colo.: Colorado Sci. Soc. Proc., vol. 8, pp. 1-30, 1905. 4 analyses of water from the springs. Discussion of chemical composition of deposits found near the springs.

16. Fisher, C. A., U. S. Geol. Survey Geol. Atlas, Nepesta folio (No. 135), 1906 (out of print). Analyses of water from 2. wells at Pueblo and 1 spring near Fowler. 
17. Darton, N. H., Geology and underground waters of the Arkansas Valley in eastern Colorado: U. S. Geol. Survey Prof. Paper 52, 1906 (out of print). Analyses (from miscellaneous sources) of well water from eastern Colorado (6), and from Dakota sandstone in southeastern Colorado (28).

18. Slichter, C. S., and Wolff, H. C., The underflow of the South Platte Valley: U. S. Geol. Survey Water-Supply Paper 184, 1906 (out of print). 52 analyses of water along the Union Pacific Railroad in western Nebraska and eastern Colorado, furnished by the railroad company.

19. Gale, H. S., Geology of the Rangely oil district, Rio Blanco County, Colo., with a section on the water supply: U. S. Geol. Survey Bull. 350, 1908 (out of print). Analysis (by R. B. Dole) of the water of White River near Rangely.

20. Headden, W. P., Notes on some mineral springs: Colorado Sci. Soc. Proc., vol. 9, p. 259, 1909. Analyses and descriptive notes of springs in Platte Canyon and in Delta County.

21. Lowther, W. H., and Knowles, R. R., The mineral waters of Steamboat Springs: Western Chemist and Metallurgist, vol. 6, p. 60, 1910. Analyses for 12 springs; rate of discharge and other data.

22. Siebenthal, C. E., Geology and water resources of the San Luis Valley, Colo.: U. S. Geol. Survey Water-Supply Paper 240, 1910 (25 cents). 17 analyses (from miscellaneous sources) of ground waters.

23. Sackett, W. G., A comparative bacteriological study of the water supply of city and county of Denver, Colo.: Colorado Agr. Exper. Sta. Bull. 225, pp. 3-14, 1917. Describes the water supply of the city and county.

24. Headden, W. P., The waters of the Rio Grande: Colorado Agr. Exper. Sta. Buli. 230, 1917. Analyses (made at Experiment Station) of water from surface sources (11) and wells (13); several analyses of alkali deposits; discussion of the irrigation problem.

25. George, R. D., Curtis, H. A., Lester, O. C., Crook, J. K., Yeo, J. B., and others, Mineral waters of Colorado: Colorado Geol. Survey Bull. 11, 1920 202 analyses (by H. A. Curtis) of mineral waters expressed in milligrams of radicle per liter, in hypothetical combinations, and in properties of reaction as proposed by Palmer (general report 9). Radioactivity determined by O. C. Lester.

26. Bastin, E. S., Silver enrichment in the San Juan Mountains, Colo.: U. S. Geol. Survey Bull. 735, pp. 65-129, 1923 (55 cents). Analyses (made by U. S. Geological Survey) of hot-spring waters from Ouray (4), mine waters from Genesee mine, Red Mountain (2), and mine waters from Dunton (3).

27. Bastin, E. S., Observations on the rich silver ores of Aspen, Colo.: U. S. Geol. Survey Bull. 750-C, 1924 (5 cents). Analyses (by Chase Palmer, U. S. Geological Survey) of 2 mine waters from Aspen, Colo.

\section{CONNECTICUT}

General reports: 1 (2), 3 (4), 4 (38), 6 (1,200 chloride determinations), 11 (5), 20 (7), 21 (7).

1. Connecticut State Board of Health reports. Most of the reports contain sanitary analyses of samples from several public supplies and from other sources.

2. Gregory, H. E., Underground water resources of Connecticut: U. S. Geol. Survey Water-Supply Paper 232, 1909 (out of print). 24 analyses from miscellaneous sources. 
3. Gregory, H. E., and Ellis, A. J., Ground water in the Hartford, Stamford, Salisbury, Willimantic, and Saybrook areas, Conn.: U. S. Geol. Survey Water-Supply Paper 374, 1916 (30 cents). 21 analyses by R. B. Dole, U. S. Geological Survey.

4. Ellis, A. J., Ground water in the Waterbury area, Conn.: U. S. Geol. Survey Water-Supply Paper 397, 1916 (15 cents). 1 analysis and 3 assays by R. B. Dole, U. S. Geological Survey.

5. Waring, G. A., Ground water in the Meriden area, Conn.: U. S. Geol. Survey Water-Supply Paper 449, 1920 (25 cents). 24 analyses made for the report by S. C. Dinsmore.

6. Palmer, H. S., Ground water in the Norwalk, Suffield, and Glastonbury areas, Conn.: U. S. Geơl. Survey Water-Supply Paper 470, 1920 (65 cents). 25 analyses and 42 assays made for the report in the water-resources laboratory of the U.S. Geological Survey.

7. Palmer, H. S., Ground water in the Southington-Granby area, Conn.: U. S. Geol. Survey Water-Supply Paper 466, 1921 (50 cents). 31 analyses and 50 assays made for the report by S. C. Dinsmore. 4 analyses made by A. A. Chambers, U. S. Geological Survey.

8. Brown, J. S., Coastal ground water, with special reference to Connecticut: U. S. Geol. Survey Water-Supply Paper 537, 1925 (20 cents). 16 analyses of well waters from the New Haven coast, with reference to probable contamination by sea water; several determinations of chloride showing contamination of well waters with sea water. Most of the analyses were made in the water-resources laboratory of the U. S. Geological Survey.

\section{DELAWARE}

General reports: $20(2)$.

\section{DISTRICT OF COLUMBIA}

General reports: $14(7), 20$ (1 s), 21 (1 s).

\section{FLORIDA}

General reports 1 (4), 3 (1), 4 (17), 14 (3), 20 (4), 21 (7), 22 (1).

1. Florida Agr. Exper. Sta. Bull. 6, pp. 5-10, 1889. 10 analysies from miscellaneous sources.

2. Sellards, E. H., Occurrence and use of artesian and other underground water: Florida Agr. Exper. Sta. Bull. 89, pp. 85-113, 1907. 10 analyses made at Experiment Station.

3. Sellards, E. H., A preliminary report on the underground water supply of central Florida: Florida Geol. Survey Bull. 1, 1908. Analyses of 14 springs and 17 wells; 8 made by U. S. Geological Survey for other reports, some made by the State chemist.

4. Sellards, E. H., and Gunter, Herman, The artesian water supply of eastern Florida: Florida Geol. Survey Third Ann. Rept., pp. 77-195, 1910.18 analyses of artesian water, many made by the State chemist.

5. Sellards, E. H., and Gunter, Herman, The underground water supply of west-central and west Florida: Florida Geol. Survey Fourth Ann. Rept., pp. 87-155, 1912. 16 analyses from miscellaneous sources.

6. Sellards, E. H., and Gunter, Herman, Artesian water supply of eastern and southern Florida: Florida Geol. Survey. Fifth Ann. Rept., pp. 103-290, 1913. Reprint from Florida 4, with additional report for southern Florida. 36 analyses from miscellaneous sources. 
7. Rose, R. E., Water analyses: Florida Dept. Agr. Quart. Bull. 21, pp. 139156, 1911. Complete analyses (13), quantities of total solids (20), quantities of solids, chloride, carbonate, and bicarbonates (37) for waters from different sources. Analyses made by State chemist.

8. Matson, G. C., and Sanford, Samuel, Geology and ground waters of Florida: U. S. Geol. Survey Water-Supply Paper 319, 1913 (out of print). 30 assays (by Samuel Sanford) of ground waters of southern Florida.

\section{GEORGIA}

General reports: $1(21), 3(10), 8(6 \mathrm{~s}), 20(5), 21(6 \mathrm{~s}, 1), 22(6)$.

1. Fuller, M. L., Peculiar mineral waters from crystalline rocks of Georgia: U. S. Geol. Survey Water-Supply Paper 160, pp. 86-91, 1906 (out of print). 5 analyses of water from wells and springs of Georgia, by Edgar Everhart, Georgia Geological Survey.

2. McCallie, S.W., A preliminary report on the underground waters of Georgia: Georgia Geol. Survey Bull. 15, 1908. 130 analyses made by Edgar Everhart and others. Some of these were used in Georgia 4.

3. McCallie, S. W., A preliminary report on the mineral springs of Georgia: Georgia Geol. Survey Bull. 20, 1913. 170 analyses by Edgar Everhart and others.

4. Stephenson, L. W., and Veatch, J. O., Underground waters of the Coastal Plain of Georgia and a discussion of the quality of the waters by R. B. Dole: U. S. Geol. Survey Water-Supply Paper 341, 1915 (50 cents). 170 analyses, mostly by Edgar Everhart; 6 tables of analyses of surface waters of Georgia from general report 8.

\section{IDAHO}

General reports: $1(2), 3(1), 10(2 \mathrm{~s}), 20(2), 21(1 \mathrm{~s}), 22(1)$.

1. McCurdy, C. W., Water and water analyses: Idaho Agr. Exper. Sta. Bull. 8,1894 . A general discussion of water and water supply, with partial analyses (made at Experiment Station) of 27 samples of water.

2. Avery, S., Report of the department of chemistry: Idaho Agr. Exper. Sta. Bull. 29, pp. 12-14, 1901. 6 sanitary analyses made at Experiment Station.

3. Kemmerer, George, Bovard, J. F., and Boorman, W. R., Northwestern lakes of the United States: U. S. Dept. Commerce Bur. Fisheries Bull. 39, pp. 51-140, 1923. Complete analyses of waters from 4 lakes in Idaho and 1 in Washington.

4. Piper, A. M., Geology and water resources of the Goose Creek basin, Cassia County, Idaho: Idaho Bur. Mines and Geology Bull. 6, 1923. 7 analyses of ground waters made by Margaret D. Foster, U. S. Geological Survey.

\section{ILLINOIS}

General reports: 1 (14), 3 (6), $14(3), 20(10), 21$ (23 s, 11), 22 (7).

1. Leverett, Frank, The water resources of Illinois: U. S. Geol. Survey Seventeenth Ann. Rept., pt. 2, pp. 695-849, 1896 (out of print). 53 analyses (by State Board of Health) of water from wells.

2. Palmer, A. W., Chemical survey of the water supply of Illinois: Illinois Univ. Prel. Rept., 1897. 1,800 sanitary analyses of surface and ground waters of the State, made in the Water Survey laboratory. 
3. Alden, W. C., U. S. Geol. Survey Geol. Atlas, Chicago folio (No. 81), 1902 (out of print). Analyses of 4 wells near Chicago.

4. Palmer, A. W., Chemical survey of the waters of Illinois: Illinois Univ. Rept., 1897-1902. About, 3,000 sanitary analyses (residue, chloride, and nitrogen) made by the State Water Survey.

5. Leighton, M. O., Pollution of Illinois and Mississippi rivers by Chicago sewage, a digest of the testimony taken in the case of the State of Missouri vs. the State of Illinois and the Sanitary District of Chicago: U. S. Geol. Survey Water- Supply Paper 194, 1907 (out of print). Several hundred sanitary analyses.

6. Bowman, Isaiah, and Reeds, C. A., Water resources of the East St. Louis district: Illinois Geol. Survey Bull. 5, 1907. 61 analyses made by the State Water Survey.

7. Udden, J. A., Artesian wells in Peoria and vicinity: Illinois Geol. Survey Bull. 8, 1907. 8 analyses made at the University of Illinois.

8. Bartow, Edward, Municipal water supplies of Illinois: Illinois Univ. Bull., Water Survey Ser. 5, 1907. Analyses (by State Water Survey) of water from 60 ground-water sources and 12 surface-water supplies; many sanitary analyses. Data on the source of supply and quality of water for cities with population of more than 1,000 (1900 census).

9. Bartow, Edward, The mineral content of Illinois waters: Illinois Univ. Bull., Water Survey Ser. 4, 1908. Same as Bull. 10, State Geol. Survey (Illinois 11 , below). 500 analyses of well waters and 30 analyses of surface waters made in Water Survey laboratory.

10. Bartow, Edward, Chemical and biological survey of the waters of Illinois: Illinois Univ. Bull., Water Survey Ser. 6, 1908, pp. 33-52, with J. M. Lindgren, Laboratory experiments in water treatment. 3 analyses of ground water. (Also in Am. Chem. Soc. Jour., vol. 29, pp. 1293-1304, 1904; and Am. Waterworks Assoc. Proc., vol. 27, pp. 505-527, 1907.) Pp. 53-58, Normal waters of Illinois.' 4 average analyses from Illinois 13.

11. Bartow, Edward, Udden, J. A., Parr, S. W., and Palmer, G. T., The mineral content of Illinois waters: Illinois Geol. Survey Bull. 10, 1909. 530 analyses by the State Water Survey (also published in Illinois 9 ).

12. Bartow, Edward, Chemical and biological survey of waters of Illinois: Illinois Univ. Bull., Water Survey Ser. 7, 1909. Pp. 98-104, The hardness of Illinois municipal water supplies (also in Illinois Soc. Engineers and Surveyors Twenty-fourth Ann. Rept., pp. 213-219, 1909). Pp. 78-97, Farm water supplies.

13. Collins, W. D., The quality of the surface waters of Illinois: U. S. Geol. Survey Water-Supply Paper 239, 1910 (10 cents). 27 series of analyses (by W. D. Collins and C. K. Calvert) covering a period of a year for the more important rivers of the area.

14. Bartow, Edward, Sanitary survey of the Vermilion River : Illinois Univ. Bull., Water Survey Ser. 9, pp. 136-146, 1912. 7 analyses of deep-well waters and 1 of Vermilion River at Streator.

15. Udden, J. A., Geology and mineral resources of the Peoria quadrangle, Ill.: U. S. Geol. Survey Bull. 506, 1912 (25 cents). 8 analyses of ground waters made at the University of Illinois.

16. Udden, J. A., and Shaw, E. W., U: S. Geol. Survey Geol. Atlas, BellevilleBreese folio (No. 195), 1915 (25 cents). Analyses of waters from 6 wells and springs, taken from Illinois 9 , above. 
17. Shaw, E. W., and Trowbridge, A. C., U. S. Geol. Survey Geol. Atlas, GalenaElizabeth folio (No. 200), 1916 (25 cents). Analyses for deep wells in Illinois (4 from Illinois 9 ) and in Iowa ( 1 from Iowa 3 ).

18. Cady, G. H., Geology and mineral resources of the Hennepin and La Salle quadrangles: Illinois Geol. Survey Bull. 37, 1919. 10 analyses of artesian water.

19. Anderson, C. B., The artesian waters of northeastern Illinois: Illinois Geol. Survey Bull. 34, 1919. 78 mineral analyses of underground waters of the area. 270 boiler analyses of underground waters (magnesium, iron, nitrate, chloride, sulphate, residue, alkalinity, and hardness). Most of the analyses were made by the State Water Survey.

20. Hinds, Henry, U. S. Geol. Survey Geol. Atlas, Colchester-Macomb folio (No. 208), 1919 (25 cents). Analyses of 6 well waters at Macomb, from Illinois 9.

21. Shaw, E. W., U. S. Geol. Survey Geol. Atlas, New Athens-Okawville folio (No. 213), 1922 (25 cents). Analysis of public supply at Mascoutah, of well water from Okawville, and 2 analyses of surface waters.

22. Savage, T. E., and Udden, J. A., The geology and mineral resources of the . Edginton and Milan quadrangles: Extract from Illinois Geol. Survey Bull. 38,1921 . 8 analyses of ground and surface waters, 22 sanitary analyses of Mississippi River at Moline.

23. Savage, T. E., and Nevel, M. L., Geology and mineral resources of the La Harpe and Good Hope quadrangles, Ill.: Illinois Geol. Survey Bull. 43, 1923. 9 analyses (from miscellaneous sources) of well waters.

\section{INDIANA}

General reports: $1(29), 3(7), 7(1), 8(4 \mathrm{~s}), 20(13), 21(4 \mathrm{~s}, 25) 22(5)$.

1. Cox, E. T., Indiana Geol. Survey Second Rept., p. 106, 1871. Chapter headed "Martin County" has section on mineral waters. 5 analyses from miscellaneous sources.

2. Leverett, Frank, The water resources of Indiana and Ohio: U.S. Geol. Survey Eighteenth Ann. Rept. pt. 4, pp. 419-560, 1897 (\$1.75). 32 analyses from miscellaneous sources.

3. Blatchley, W. S., The mineral waters of Indiana: Indiana Dept. Geology and Nat. Res. Twenty-sixth Ann. Rept., pp. 11-158, 1903. (This annual report gives on pp. 159-226 an article by Robert Hessler on the medicinal properties and use of Indiana waters). 80 analyses from miscellaneous sources.

4. Capps, S. R., The underground waters of north-central Indiana, with a chapter on the chemical character of the waters by R. B. Dole: U.S. Geol. Survey Water-Supply Paper 254, 1910 (40 cents). 320 analyses of ground water and 13 analyses of surface water, made in laboratories of U. S. Geological Survey and State Board of Health.

\section{IOWA}

General reports: 1 (14), 3 (5), 8 (4 s), $14(2), 20(12), 21$ (3 s, 33), 22 (3).

1. Norton, W. H., Report on lead, zinc, artesian wells in Iowa: Iowa Geol. Survey, vol. 6, 1897. Analyses (from miscellaneous sources) of waters from rivers (20), artesian wells (50), shallow,wells (33), wells in drift (11). Contains a bibliography on waters from artesian wells. 
2. Grant, U. S., and Burchard, E. F., U. S. Geol. Survey Geol. Atlas, LancasterMineral Point folio (No. 145), 1907 (5 cents). Analyses (from Iowa 1) of water from 2 artesian wells near Dubuque.

3. Norton, W. H., Hendrixson, W. S., Simpson, H. E., Meinzer, O. E., and others, Underground water resources of Iowa: U. S. Geol. Survey Water-Supply Paper 293, 1912 (70 cents). 400 analyses of ground waters. Nearly onehalf were made by W.S. Hendrixson in the chemical laboratory of Grinnell College; 45 were taken from Iowa 1; the rest were obtained from railroads and other sources.

4. Norton W. H., and others, Underground water resources of Iowa: Iowa Geol. Survey, vol. 21, pp. 29-1186, 1912. 400 analyses of well waters, which are given in Iowa 3.

5. Gabriel, G. A., River waters in Iowa-a preliminary report: Iowa Geol. Survey, vol. 26, pp. 29-48, 1917. 9 tables of analyses of waters of Cedar, Des Moines, and Iowa rivers.

6. Knight, Nicholas, Some Iowa waters: Iowa Acad. Sci. Proc., vol. 15, pp. 109-110, 1908. 5 analyses including public supplies of Springville and Lisbon.

\section{KANSAS}

General reports: 1 (24), 3 (13), 15 (8), 18 (14), 20 (3), 21 (24 s, 116), 22 (17).

1. Bailey, E. H. S., and Franklin, E. C., A chemical examination of the waters of the Kaw River and its tributaries: Kansas Univ. Quart., vol. 3, p. 91, 1895. 9 analyses of surface waters made at the University. The methods used are described.

2. Bailey E. H. S., Special report on mineral waters: Kansas Univ. Geol. Survey, vol. 7,1902 . 129 analyses of mineral waters made by the author-

3. Slichter, C. S., The underflow in Arkansas Valley in western Kansas: U. S. Geol. Survey Water-Supply Paper 153, 1906 (out of print). 70 assays of ground waters made in the field.

4. Wolff, H. C., The utilization of the underflow near St. Francis, Kans.: U. S. Geol. Survey Water-Supply Paper 258, pp. 98-119, 1911 (out of print). Field assays of 19 well waters made by the author.

5. Parker, H. N., Quality. of the water supplies of Kansas, with a preliminary report on stream pollution by mine waters in southeastern Kansas by E. H. S. Bailey: U. S. Geol. Survey Water-Supply Paper 273, 1911 (30 cents). 25 tables of series of analyses of composites of daily samples of surface waters; 150 single analyses and 250 assays. 500 analyses and 500 assays of ground water. Most of the analyses were made under the direction of E. H. S. Bailey at the University of Kansas. Most of the field assays were made by $\mathrm{H}$. N. Parker. A number of analyses were obtained from testing laboratories of railroads.

6. Haskins, C. A., and Young, C. C., Water supplies of Kansas: Kansas Univ. Bull., vol. 16., No. 10, 1915. 150 analyses (made at the University) of water from public supplies.

7. Meinzer, O. E., Preliminary report on ground water for irrigation in the vicinity of Wichita, Kans.: U. S. Geol. Survey Water-Supply Paper 345, pp. 1-9, 1915 (30 cents). Determinations of total solids, bicarbonate, sulphate, and chloride for 37 ground waters.

8. Darton, N. H., U. S. Geol. Survey Geol. Atlas, Syracuse-Lakin folio (No. 212), 1920 (25 cents). Analyses (by Atchison, Topeka \& Santa Fe Railway) of 20 well waters. 


\section{KENTUCKY}

General reports: $1(80), 3(15), 4(2), 7(1), 8$ (3 s), 14 (1), 15 (12), 20 (3), $21(3 \mathrm{~s}, 2), 22(6)$.

1. Kentucky Agr. Exper. Sta. Ann. Repts. Reports for each year from 1894 to 1917 contain from 1 to 10 complete analyses and from 1 to 60 partial analyses, all made at the Experiment Station. Many of the partial analyses give only the total solids.

2. Peter, Robert, Chemical report: Kentucky Geol. Survey Rept. 3, pt. 2, 1857. 13 analyses (by the Survey) of mineral waters.

-3. Peter, Robert, First, second, and third chemical reports; Kentucky Geol. Survey, 1884. Analyses (by author) of mineral waters, from 1875 report (20), 1877 report (17), 1878 report (16).

4. Peter, Robert. and Peter, A. M., Fourth, fifth, and sixth chemical reports: Kentucky Geol. Survey Chem. Analyses A 2, 1885. Analyses (by authors) of mineral waters from 1879 report (2), 1883 report (20), 1884 report (6).

5. Peter, Robert, and Peter, A. M., Chemical reports: Kentucky Geol. Survey Chemical Analyses A 3, 1888. 8 analyses (by authors) of mineral waters.

6. Foerste, A. F., The Silurian, Devonian, and Irvine formations of east-central Kentucky: Kentucky Geol. Survey Bull. 7, 1906. 30 analyses (by the Survey) of mineral springs.

7. Glenn, L. C., Underground waters of Tennessee and Kentucky west of Tennessee River and of an adjacent area in Illinois (Tennesee 1, below): U. S. Geol. Survey Water-Supply Paper 164, 1906 (25 cents). Analyses of water from wells at Wickliffe (2) and McGee Spring, Ballard County (1). 12 analyses of waters from Tennessee.

8. Matson, G. C., Water resources of the Blue Grass region, Ky., with a chapter on the quality of the waters, by Chase Palmer: U. S. Geol. Survey Water-Supply Paper 233, 1909 (20 cents). 74 analyses (by Chase Palmer) of ground waters, 20 analyses from miscellaneous sources of spring waters, 60 field assays by Palmer.।

9. Crider, A. F., Geology of the Dawson Springs quadrangle: Kentucky Geol. Survey, ser. 4, vol. 2, pt. 1, 1914. 11 analyses (by Survey) of mineral waters.

10. Shaw, E. W., The Irvine oil field, Estill County, Ky.: U. S. Geol. Survey Bull. 661, pp. 141-192, 1918 (Bull. 661-D, 15 cents). 4 analyses of water from Estill Springs.

11. McHargue, J. S., and Peter, A. M., The removal of mineral plant-food by natural waters: Kentucky Agr. Exper. Sta. Bull. 237, 1921. Analyses (made at Experiment Station) of ground and surface waters from Fayette and Woodford counties (17), waters from Mississippi and Pennsylvania areas (11), Mississippi River system (16), other river waters (8).

\section{LOUISIANA}

General reports: $8(2 \mathrm{~s}), 20(4), 21(2 \mathrm{~s}, 1), 22(3)$.

1. Veatch, A. C., The salines of north Louisiana: Geology and agriculture of Louisiana, pt. 6, pp. 47-100, Louisiana State Exper. Sta. 1902. Analyses (from miscellaneous sources) of brines of Louisiana (10) and of other parts of the country (46). 18 partial analyses of artesian waters.

2. Stubbs, W. C., Dodson, W. R., and Brown, C. A., Rice: Louisiana Agr. Exper. Sta. Bull. 77, 2d ser., pp. 382-385, 1904. 22 partial analyses (made at Experiment Station) of waters used in the irrigation of rice fields; 18 of these are from Louisiana 1. 
3. Harris, G. D., Underground waters of southern Louisiana, with discussions of their uses for water supplies and for rice irrigation by M. L. Fuller U. S. Geol. Survey Water-Supply Paper 101, 1904 (20 cents). 18 analyses of water from artesian wells taken from Louisiana 1.

4. Harris, G. D., Veatch, A. C., and others, Underground waters of southern Louisiana: Louisiana Geol. Survey Bull. 1, pp. 1-77, 1905. 'Analyses of water from the public supply at Baton Rouge and from 2 other sources. 18 partial analyses from Louisiana 1.

5. Veatch, A. C., Geology and underground water resources of northern Louisiana and southern Arkansas: U. S. Geol. Survey Prof. Paper 46, 1906 (out of print). Analyses (from miscellaneous sources) of water from wells of Louisiana (22), Arkansas (10), Mississippi (1), Texas (2).

6. Veatch, A. C., Geology and underground water resources of northern Louisiana: Louisiana Geol. Survey Bull. 4, 1906. Excerpts from Louisiana 5. Analyses of ground waters (13) and brines (10). Some of the brine analyses are from Louisiana 1.

\section{MAINE}

General reports: 1 (22), 3 (8), 4 (6), 6 (120 chloride determinations), 7 (1), 8 (1 s), $11(8), 20(2), 21(2 \mathrm{~s}, 12), 22(4)$.

1. Maine State Board of Health Ann. Repts. Most of the reports contain sanitary analyses of samples from public supplies and other sources.

2. Bayley, W. S., Occurrence of underground waters of Maine: U. S. Geol. Survey Water-Supply Paper 114, 1905 (out of print). 22 analyses (from miscellaneous sources) of spring waters.

3. Barrows, H. K., Water resources of the Kennebec River basin, Maine, with a section on the quality of the Kennebec River water, by G. C. Whipple: U. S. Geol. Survey Water-Supply Paper 198, 1907 (30 cents). 20 sanitary analyses of the river water.

4. Clapp, F. G., Underground waters of southern Maine, with records of deep wells by W. S. Bayley: U. S. Geol. Survey Water-Supply Paper 223, 1909 (55 cents). 9 analyses of spring waters by W. W. Skinner. Analyses and assays (from miscellaneous sources) of spring waters (88), and well waters (202).

5. Clapp, F. G., Occurrence and composition of well waters in the slates of Maine: U. S. Geol. Survey Water-Supply Paper 258, pp. 32-39, 1911 (out of print). 13 analyses by F. C. Robinson.

6. Clapp, F. G., Occurrence and composition of well waters in the granites of New England: U. S. Geol. Survey Water-Supply Paper 258, pp. 40-47, 1911 (out of print). 7 analyses by F. C. Robinson.

7. Clapp, F. G., Composition of mineral springs in Maine: U. S. Geol. Survey Water-Supply Paper 258, pp. 66-74, 1911 (out of print). 11 analyses from miscellaneous sources.

\section{MARYLAND}

General reports: 1 (4), 2 (2), 3 (5), 7 (3), 8 (1 s), 20 (2), 21 (1 s, 17), 22 (2).

1. Clark, W. B., Mathews, E. B., and Berry, E. W., The surface and underground water resources of Maryland, including Delaware and the District of Columbia: Maryland Geol. Survey, vol. 10, 1918. 95 analyses of ground waters by Penniman \& Browne and others. 150 sanitary analyses made by the State Board of Health. Descriptions of public water supplies with analyses. 


\section{MASSACHUSETTS}

General reports: 1 (8), 3 (5), 4 (24), 5 (2), 6 (60 chloride determinations), 11 (13) $20(2), 21(3)$.

1. Massachusetts Agr. Exper. Sta. Ann. Repts. (Pub. Doc. 33). Reports for each year from 1888 to 1894 contain from 65 to 200 sanitary analyses made at the Experiment Station.

2. Massachusetts State Dept. Public Health Ann. Repts. Most of these reports contain sanitary analyses of samples from all the public supplies of the State and from some miscellaneous sources.

\section{MICHIGAN}

General reports: $1(29), 3$ (28), 4 (26), 7 (1), 8 (5 s), 13 (8), 14 (1), 16 (5), 17 (9), $18(36), 20(13), 21(6 \mathrm{~s}, 26), 22(9)$.

1. Houghton, Douglass, Report of the State Geologist in relation to the improvement of the State salt springs: Michigan House of Representatives Doc. 2, 1839. 12 analyses of the New York brines (by Professor Goesman, of Syracuse), and discussion of the Michigan brines.

2. Lane, A. C., Lower Michigan mineral waters, a study into the connection between their chemical composition and mode of occurrence: U. S. Geol. Survey Water-Supply Paper 31, 1899 (10 cents). Over 300 analyses (from miscellaneous sources) of surface and ground waters.

3. Leverett, Frank, and others, Flowing wells and municipal water supplies in the southern portion of the southern peninsula of Michigan: U. S. Geol. Survey Water-Supply Paper 182, 1906 (50 cents). 20 complete and 80 partial analyses, from miscellaneous sources.

4. Leverett, Frank, and others, Flowing wells and municipal water supplies in the middle and northern portions of the southern peninsula of Michigan: U. S. Geol. Survey Water-Supply Paper 183, 1907 (50 cents). 12 analyses of well and spring waters and 50 partial and field analyses, from miscellaneous sources.

5. Russell, I. C., and Leverett, Frank, U. S. Geol. Survey Geol. Atlas, Ann Arbor folio (No. 155), 1908 (5 cents). Analyses of 5 mineral waters.

6. Lane, A. C., The Keweenaw series of Michigan: Michigan Geol. and Biol. Survey Pub. 6, Geol. Ser. 4, 1911. 50 analyses (from miscellaneous sources) of mine waters.

7. Cook, C. W., The brine and salt deposits of Michigan: Michigan Geol. and Biol. Survey Pub. 15, Geol. Ser. 12, 1914. 90 analyses of brines and bitterns of the State. Most of these have been published before. In some analyses the units are not given and therefore the concentration is not shown.

8. Sherzer, W. H., U. S. Geol. Survey Geol. Atlas, Detroit folio (No. 205), 1917 (50 cents). Analyses (from other publications) of brines (11), surface waters (2), salt mine and well (3).

\section{MINNESOTA}

General reports: $1(7), 4(1), 8(2 \cdot s), 20(5), 21(2 \mathrm{~s}, 45), 22(10)$.

1. Upham, Warren, The glacial Lake Agassiz: U. S. Geol. Survey Mon. 25, 1896 (\$1.70). Analyses (from miscellaneous sources) of water from Minnesota (10), Manitoba (1), North Dakota (1).

2. Dole, R. B., and Wesbrook, F. F., The quality of surface waters in Minnesota: U. S. Geol. Survey Water-Supply Paper 193, 1907 (25 cents). Over $\$ 00$ partial analyses made by $R$. B. Dole and others. 
3. Hall, C. W., Meinzer, O. E., and Fuller, M. L., Geology and underground waters of southern Minnesota: U. S. Geol. Survey Water-Supply Paper 256,1911 (60 cents). 400 analyses obtained from testing laboratories of railroads and from other sources.

4. Sardeson, F. W., U. S. Geol. Survey Geol. Atlas, Minneapolis-St. Paul folio (No. 201), 1916 (25 cents). 10 analyses of ground waters from Minnesota 3 , and 2 of surface waters from general report 8 .

\section{MISSISSIPPI}

General reports: 1 (4), 3 (8), 8 (1 s), $14(1), 20(2), 21$ (1 s), 22 (1).

1. Mississippi Agr. Exper. Sta. Twelfth Ann. Rept., p. 41, 1899. 6 analyses of artesian waters made at the Experiment Station.

2. Logan, W. N., and Perkins, W. R., Underground waters of Mississippi: Mississippi Agr. Exper. Sta. Bull 89, 1905. 75 analyses made at the Experiment Station.

3. Crider, A. F., and Johnson, L. C., Summary of the underground-water resources of Mississippi: U. S. Geol. Survey Water-Supply Paper 159, 1906 (20 cents). 99 analyses of ground water; 67 are from Mississippi 2.

\section{MISSOURI}

General reports: 1 (28), 3 (8), 4 (48), 8 (2 s), 14 (9), 15 (29), 16 (7), 20 (4), 21 $(1 \mathrm{~s}, 17), 22$ (11).

1. Woodward, A. E., The mineral waters of Saline County: Missouri Geol. Survey Bull. 1, p. 45, 1890. 11 analyses of Missouri waters and 7 others.

2. Woodward, A. E., The mineral water of Henry, St. Clair, Johnson, and Benton counties: Missouri Geol. Survey Bull. 3, p. 85, 1890. 12 analyses of Missouri waters and 6 others.

3. Schweitzer, Paul, Report on the mineral waters of Missouri: Missouri Geol. Survey, vol. 3, 1892. 83 analyses made for the report by A. E. Woodward and Paul Schweitzer, 15 analyses of foreign mineral waters, about 100 additional analyses-of mineral waters of the State from miscellaneous sources. A bibliography of about 200 titles of publications on mineral waters from 1500 to 1883 .

4. Gallaher, J. A., Preliminary report on the structural and economic geology of Missouri: Missouri Bur. Geology and Mines, vol. 13, 1900. 41 analyses of mineral waters taken from Missouri 3.

5. Smith, W. S. T., Water resources of the Joplin district, Mo.-Kans.; U. S. Geol. Survey Water-Supply Paper 145, pp. 74-83, 1905 (out of print). Analyses (from miscellaneous sources) of waters from springs (6) and from deep wells (6).

6. Shepard, E. M., Underground waters of Missouri, their geology and utilization; U. S. Geol. Survey Water-Supply Paper 195, 1907 (30 cents). Analyses (from miscellaneous sources) of waters from city supplies (24) and from wells and springs (60).

7. Buckley, E. R., Geology of the disseminated lead deposits of St. Francois and Washington counties; Missouri Bur. Geology and Mines, vol. 9, pt. 1, 1909. Analyses (from miscellaneous sources) of 11 mine waters.

8. McCourt, W. E., The geology of Jackson County; Missouri Bur. Geology and-Mines, vol. 14, 2d ser., 1917. Analyses (from miscellaneous sources) of waters from rivers (2), wells and springs (8). 


\section{MONTANA}

General reports: 1 (8), $3(3), 10(4 \mathrm{~s}), 12(7), 14(13), 15(2), 16(6), 20(2), 21$ (4), 22 (1).

1. Fisher, C. A., Geology and water resources of the Great Falls region, Mont.: U. S. Geol. Survey Water-Supply Paper 221, 1909 (20 cents). 80 assays from miscellaneous sources.

2. Meinzer, O. E., The water resources of Butte, Mont.: U. S. Geol. Survey Water-Supply Paper 345, pp. 79-105, 1915 (30 cents). 8 analyses made for the report by S. C. Dinsmore, 13 from railroad laboratories, 7 analyses of mine waters given in general report 14 .

3. Meinzer, O. E., Artesian water for irrigation in Little Bitterroot Valley, Mont.: U. S. Geol. Survey Water-Supply Paper 400, pp. 9-37, 1917 (15 cents). 14 analyses of ground waters made by S. C. Dinsmore, Carl Gottschalk, and W. M. Cobleigh, for the U. S. Geological Survey.

4. Ellis, A. J., and Meinzer, O. E., Ground water in Musselshell and Golden Valley counties, Mont.: U. S. Geol. Survey Water-Supply Paper 518, 1924 (20 cents). Analyses (from miscellaneous sources) of water from Musselshell River (10) and from wells and springs (51).

5. Pardee, J. T., Geology and ground-water resources of Townsend Valley, Mont.: U. S. Geol. Survey Water-Supply Paper 539, 1925 (15 cents). 12 analyses by C. S. Howard, U. S. Geological Survey.

6. Reeves, Frank, Geology and possible oil and gas resources of the faulted area south of the Bearpaw Mountains, Mont.: U. S. Geol. Survey Bull. 751, pp. 71-114, 1924 (Bull. 751-C, 15 cents). Analyses (by C. S. Howard) of water from sands at 2,855 and 3,177 feet in a test well near Winifred.

\section{NEBRASKA}

General reports: $3(1), 8(4 \mathrm{~s}), 20(2), 21(4 \mathrm{~s}, 14), 22(3)$.

1. Slichter, C. S., and Wolff, H. C., The underflow of the South Platte Valley: U. S. Geol. Survey Water-Supply Paper 184, 1906 (out of print). 52 analyses of water along the Union Pacific Railroad in western Nebraska and eastern Colorado, made in the railroad testing laboratory; 30 field assays.

2. Condra, G. E., Geology and water resources of a portion of the Missouri River valley in northeastern Nebraska; U. S. Geol. Survey Water-Supply Paper 215, 1908 (40 cents). 3 analyses of artesian waters.

3. Meinzer, O. E., Ground water for irrigation in Lodgepole Valley, Wyo. and Nebr.: U. S. Geol. Survey Water-Supply Paper 425, pp. 37-69, 1919 (out of print) (Wyoming 9). 10 analyses of waters from Nebraska and 12 from Wyoming made by S. C. Dinsmore and others.

\section{NEVADA}

General Reports: 1 (6), 3 (1), 10 (2 s), 12 (8), 14 (18), 16 (9), 20 (2), 21 (12), $22(10)$.

1. Wilson, N. E., Drinking water: Nevada Agr. Exper. Sta. Bull. 34, 1896. 79 sanitary analyses made at the Experiment Station.

2. Nevada Agr. Exper. Sta. Bull. 72, pp. 40-44, 1909. Analyses (made at Experiment Station) of water from public supplies of Dixie, Elko City, Mazuma, Rawhide, Reno, and Yerrington.

3. Hance, J. H., Potash in western saline deposits: U. S. Geol. Survey Bull. 540 , pp. $457-469,1914$ (out of print). Quantities of soluble material and potash for about 100 samples of residues and brines, total solids for 31 spring and well waters. Analyses made for the report by A. R. Merz, 
4. Dole, R. B., Exploration of salines in Silver Peak Marsh, Nev.: U. S. Geol. Survey Bull. 530, pp. 330-345, 1913 (out of print). 12 analyses of waters by Walton Van Winkle (also given in Nevada 7). 13 partial analyses of brines by Van Winkle, 13 determinations of total solids and potassium in brines by A. R. Merz.

5. Carpenter, Everett, Ground water in southeastern Nevada: U. S. Geol. Survey Water-Supply Paper 365, 1915 (out of print). 42 analyses of ground and surface waters made by S. C. Dinsmore.

6. Hicks, W. B., The composition of muds from Columbus Marsh, Nev.: U. S. Geol. Survey Prof. Paper 95, pp. 1-11,1916 (20 cents). 9 partial analyses (by author) of waters from a test well.

7. Meinzer, O. E., Geology and water resources of Big Smoky, Clayton, and Alkali Spring valleys, Nev.: U. S. Geol. Survey Water-Supply Paper 423, 1917 (30 cents). 60 analyses of ground water, most of them by S. C. Dinsmore (12 are from Nevada 4).

8. Bastin, E. S., and Laney, F. B., The genesis of the ores at Tonopah, Nev。: U. S. Geol. Survey Prof. Paper 104, 1918 (15 cents). 3 analyses of mine waters by Chase Palmer and R. C. Wells, U. S. Geological Survey.

9. Waring, G. A., Ground water in Reese River basin and adjacent parts of Humboldt River basin, Nev.: U. S. Geol. Survey Water-Supply Paper 425, pp. 95-129, 1919 (out of print). 37 analyses made for the report by S. C. Dinsmore.

10. Clark, W. O., and Riddell, C. W., Exploratory drilling for water and use of ground water for irrigation in Steptoe Valley, Nev.: U. S. Geol. Survey Water-Supply Paper 467, 1920 (out of print). 16 analyses and 10 assays of well and spring.waters, 7 analyses and 3 assays of water from test wells, made for this report in the water-resources laboratory, U. S. Geological Survey.

11. Waring, G. A., Ground water in Pahrump, Mesquite, and Ivanpah valleys, Nev. and Calif.: U. S. Geol. Survey Water-Supply Paper 450, pp. 51-86, 1921 (Water-Supply Paper 450-C, 5 cents) (California 34). Analyses (made for the report) of ground waters from Nevada (8) and California (12).

12. Bastin, E. S., Bonanza ores of the Comstock lode, Virginia City, Nev.: U. S. Geol. Survey Bull. 735, pp. 41-63, 1923 (Bull. 735-C, 5 cents). 2 analyses of mine waters by N. E. Wilson, University of Nevada; 1 by Chase Palmer, U. S. Geological Survey.

\section{NEW HAMPSHIRE}

General reports: 1 (8), 3 (2), 4 (20), 6 (150 chloride determinations), 7 (1), 11 (6), $21(8), 22(1)$.

1. New Hampshire State Board of Health Repts. Most of the reports contain sanitary analyses (residue is not given) of samples of public supplies and other waters.

\section{NEW JERSEY}

General reports: 1 (8), 2 (9), 3 (3), 8 (2 s), $20(9), 21(2 \mathrm{~s}, 1), 22(2)$.

1. New Jersey State Dept. Health Repts. Many of the reports contain partial analyses of samples from public supplies of the State.

2. Cook, G. H., State Geologist, Ann. Rept. 1868, pp. 701-708. 12 analyses from miscellaneous sources.

3. Cook, G. H., State Geologist, Ann. Rept. 1876. 23 partial analyses from misçęllanẹous soưrcẹs, 
4. Cook, G. H., State Geologist, Ann. Rept. 1879, pp. 123-150. 4 analyses from miscellaneous sources.

5. Cook, G. H., State Geologist, Ann. Rept. 1884, pp. 121-150. 7 analyses from miscellaneous sources.

6. Vermeule, C. C., Report on water supply: State Geologist Final Report. vol. 3, 1894. 40 more or less complete analyses from miscellaneous sources.

\section{NEW MEXICO -}

General reports: $1(12), 3(3), 10(8 \mathrm{~s}), 14(3), 20(2), 21(4), 22(4)$.

1. Goss, Arthur, and Holt, A. M., New Mexico sugar beets: New Mexico Agr. Exper. Sta. Bull. 29, pp. 197-203, 1899. 12 analyses of samples from the Rio Grande, collected monthly from June, 1893, to June 1894. 9 analyses of other waters, all made at the Experiment Station.

2. Goss, Arthur, Principles of water analysis as applied to New Mexico waters: New Mexico Agr. Exper. Sta. Bull. 34, 1900. Sanitary and mineral analyses of 148 samples of stream, spring, and well waters, made at Experiment Station in previous 8 years.

3. Fisher, C. A., Preliminary report on the geology and underground waters of the Roswell artesian area, N. Mex.: U. S. Geol. Survey Water-Supply Paper 158, 1906 (out of print). Analyses of 20 spring waters by $\mathbf{E}$. M. Skeetz. Analyses (from miscellaneous sources) of 12 artesian waters and 2 river waters.

4. Lee, W. T., Water resources of the Rio Grande Valley in New Mexico and their development: U. S. Geol. Survey Water-Supply Paper 188, 1907 (out of print). 35 analyses of ground water, made by R. F. Hare, of the New Mexico Experiment Station, and by other analysts. 12 analyses from New Mexico 2 above.

5. Meinzer, O. E., Preliminary report on the ground waters of Estancia Valley, N. Mex.: U. S. Geol. Survey Water-Supply Paper 260, 1910 (out of print). 84 field assays of ground waters (also in New Mexico 6).

6. Meinzer, O. E., Geology and water resources of Estancia Valley, N. Mex., with notes on ground-water conditions in adjacent parts of central New Mexico: U. S. Geol. Survey Water-Supply Paper 275, 1911 (out of print). 84 field assays of ground waters (also given in New Mexico 5).

7. Hare, R. F., and Mitchell, S. R., Composition of some New Mexico waters, with discussion of their fitness for irrigation and domestic purposes: New Mexico Agr. Exper. Sta. Bull. 83, 1912. About 350 analyses of surface and ground waters, one-half complete, the others sanitary or partial. Made at Experiment Station in the previous 10 years.

8. Kelly, C., and Anspach, E. V., A preliminary study of the waters of the Jemez Plateau, N. Mex.: New Mexico Univ. Bull. 71, 1913. 11 analyses (by the authors) of water from springs.

9. Meinzer, O. E., and Hare, R. F., Geology and water resources of Tularosa Basin, N. Mex.: U. S. Geol. Survey Water-Supply Paper 343, 1915 (out of print). About 170 analyses of ground waters and 10 surface waters, mostly made at the New Mexico Agricultural Experiment Station under the supervision of R. F. Hare.

10. Darton, N. H., Geology and underground water of Luna County, N. Mex.: U. S. Geol. Survey Bull. 618, 1916 (20 cents). 9 analyses made in railroad laboratories.

11. Darton, N. H., U. S. Geol. Survey Geol. Atlas, Deming folio (No. 207), 1917 (25 cents). Analyses for 2 wells near Deming.

$50065^{\circ}-25-6$ 
12. Schwennesen, A. T., Ground water in the Animas, Playas, Hachita, and San Luis basins, N. Mex., with analyses of water and soil by R. F. Hare: U. S. Geol. Survey Water-Supply Paper 422, 1918 (20 cents). 60 analyses of well and spring waters made by R. F. Hare, New Mexico Experiment Station.

13. Schwennesen, A. T., Ground water in the San Simon Valley, Ariz. and N. Mex.: U. S. Geol. Survey Water-Supply Paper 425, pp. 1-35, 1919 (out of print). 14 analyses of well and spring waters made by A. E. Vinson and D. W. Moore, Arizona Agricultural Experiment Station.

\section{NEW YORK}

General reports: 1 (93), 3 (61), 4 (14), 6 (100 chloride determinations), 7 (20) $8(4 \mathrm{~s}), 13(6), 18(39), 20(12), 21(3 \mathrm{~s}, 12), 22(13)$.

1. New York State Dept. Health Repts. Most of the reports contain data on several public supplies of the State; some sanitary analyses are also reported.

2. Leighton, M. O., Quality of water in the Susquehanna River drainage basin: U. S. Geol. Survey Water-Supply Paper 108, 1904 (out of print) (Pennsylvania 1). Total solids, incrustants, nonincrustants, and chloride for about 200 surface and ground waters of the area; nitrogen, chloride, total residue, and iron for about 100 surface waters. Most of the area covered by this report is in Pennsylvania.

3. Veatch, A. C., Slichter, C. S., Bowman, Isaiah, Crosby, W. O., and Horton, R. E., Underground water resources of Long Island, N. Y.: U. S. Geol. Survey Prof. Paper 44, 1906 (out of print). 25 analyses from miscellaneous sources.

4. Kemp, J. F., The mineral springs of Saratoga: New York State Mus. Bull. 159, 1912. 110 analyses (from miscellaneous sources) of the waters of Saratoga Springs, covering many years.

5. Milford, L. R., Analyses of the Saratoga mineral waters: Jour. Ind. and Eng. Chemistry, vol. 4, p. 593, 1912; vol. 5. pp. 24, 557, 1913; vol. 6, p. 207, 1914. Analyses (by the author) of the important Saratoga waters.

\section{NORTH CAROLINA}

General reports: $1(20), 3(7), 7(1), 8(3 \mathrm{~s}), 14(1), 15(2), 20(2), 21(3 \mathrm{~s}), 22$ (4). 1. Blair, A. W., Drinking water, city, town, and rural supplies: North Carolina Agr. Exper. Sta. Bull. 161, 1899. Total solids, chloride, hardness, and ammonia for 88 samples of water determined at the Experiment Station.

2. Pratt, J. H., The mining industry in North Carolina during 1907, with a special report on the mineral waters: North Carolina Geol. and Econ. Survey Econ. Paper. 15, p. 74, 1908. 80 analyses of mineral waters made at the State University.

3. Clark, W. B., Miller, B. L., Stephenson, L. W., Johnson, B. L., and Parker, H. N., The Coastal Plain of North Carolina: North Carolina Geol. and Econ. Survey, vol. 3, pp. 333-502, 1912. 45 partial analyses from miscellaneous sources. 188 assays made for the report.

\section{NORTH DAKOTA}

General reports: 1 (6), 20 (3), 21 (22), 22 (1).

1. Darton, N. H., Preliminary report on artesian waters of a portion of the Dakotas: U. S. Geol. Survey, Seventeenth Ann. Rept., pt. 2, pp. 603-694, 1896 (out of print). 23 analyses from mișcellaneous sources, 
2. Ladd, E. F., Drinking water: North Dakota Agr. Exper. Sta. Bull. 32, pp. 267-270, 1898. Quantities of total solids and sodium chloride for 20 samples of artesian water, with complete analyses of 3 .samples, made at the Experiment Station.

3. Jensen, C. A., and Neill, N. P., Soil survey of the Grand Forks area, N. Dak.: North Dakota Agr. Coll. Survey, Second Bienn. Rept., pp. 35-58, 1904 (reprint from Field Operations, U. S. Bur. Soils, 1902). 37 partial analyses from miscellaneous sources.

4. Ladd, E. F., Waters of North Dakota: North Dakota Agr. Exper. Sta. Bull. 66 , pp. 559-571, 1905 . Tests of 160 samples of waters made at the Experiment Station.

5. Ladd, E.F., Special food bulletin: North Dakota Agr. Exper. Sta., Food Dept., vol. 1, pp. 166-167, 1910. Tests of 35 samples of drinking water made at the Experiment Station.

6. Ladd, E. F., North Dakota waters: North Dakota Agr. Exper. Sta. Twentythird Ann. Rept., pt. 3, pp. 449-483, 1912. Total solids and chloride are reported for 725 waters tested at the Experiment Station.

\section{OHIO}

General reports: 1 (15), 3 (8), 8 (3 s), 13 (5), 17 (6), 18 (32), 19 (21), 20 (13). $21(3 \mathrm{~s}, 31), 22(5)$.

1. Leverett, Frank, The water resources of Indiana and Ohio: U. S. Geol. Survey Eighteenth Ann. Rept., pt. 4, p. 495, 1897 (\$1.75). 31 analyses (from miscellaneous sources) of waters from Ohio.

2. Orton, Edward, The rock waters of Ohio: U. S. Geol. Survey Nineteenth Ann. Rept., pt. 4, pp. 633-717, 1899 (\$1.85). 24 analyses from miscellaneous sources.

3. Fuller, M. L., and Clapp, F. G., The underground waters of southwestern Ohio, with a discussion of the chemical character of the waters by $\mathbf{R}$. B. Dole: U. S. Geol. Survey Water-Supply Paper 259, 1912 (35 cents). 200 analyses and field assays of ground waters by R. B. Dole and others, 40 analyses (from miscellaneous sources) of surface waters.

4. Hubbard, G. D., Stauffer, C. R., Bownocker, J. A., Prosser, C. S., and Cumings, E. R., U. S. Geol. Survey Geol. Atlas, Columbus folio (No. 197), 1915 (25 cents). Partial analyses for 8 wells near Columbus; averages of partial analyses for Scioto River at Columbus.

\section{OKLAHOMA}

General reports: 10 (4 s), $14(3), 15(12), 20(3), 21$ (1).

1. Holter; G. L., and Fields, John, A study of waters for irrigation: Oklahoms Agr. Exper. Sta. Bull. 29, pp.3-14, 1897. Analyses (made at the Experiment Station) of surface waters (14), ground waters (12), and 12 sanitary analyses. Oklahoma Agr. Exper. Sta. Bull. 38, pp. 3-7, has most of the data in Bulletin 29 and a few more analyses.

2. Oklahoma Agr. Exper. Sta. Rept., 1900, pp. 73-75. 18 analyses made at the Experiment Station.

3. Ford, A. G., Miscellaneous water analyses: Oklahoma Agr. Exper. Sta. Bull. 67, 1905. 125 analyses made at the Experiment Station, most of which represent ground water. About half are complete analyses.

4. Gould, C. N., Geology and water resources of Oklahoma: U. S. Geol. Survey Water-Supply Paper 148, 1905 (out of print). Analyses of waters from streams (50), springs (15), wells (85), ponds (3), made by Edwin DeBarr at the University of Oklahoma. 
5. Schwennesen, A. T., Ground water for irrigation in the valley of North Fork of Canadian River near Oklahoma City, Okla.: U. S. Geol. Survey WaterSupply Paper 345, pp. 41-51, 1915 (30 cents). 7 partial analyses of water from alluvium.

6. Thompson, D. G., Ground water for irrigation near Gage, Ellis County, Okla.: U. S. Geol. Survey Water-Supply Paper 500, pp. 33-53, 1922 (WaterSupply Paper 500-B, 5 cents). 4 assays of ground water made for the report in the water-resources laboratory of the U. S. Geological Survey.

7. Renick, B. C., Additional ground-water supplies for the city of Enid, Okla.: U. S. Geol. Survey Water-Supply Paper 520-B, 1924 (5 cents). 5 analyses made by C. S. Howard, U. S. Geological Survey.

\section{OREGON}

General reports: 1 (8), $3(4), 10(2 \mathrm{~s}), 14(2), 21$ (23 s, 41), 22 (24).

1. Waring G. A., Geology and water resources of a portion of south-central Oregon: U. S. Geol. Survey Water-Supply Paper 220, 1908 (20 cents). 6 analyses made by W. H. Heileman, Berkeley, Calif.

2. Van Winkle, Walton, Quality of the surface waters of Oregon: U. S. Geol. Survey Water-Supply Paper 363, 1914 (20 cents). 26 tables containing series of analyses covering a period of about a year, 50 single analyses of surface waters. Most of the analyses were made by the author.

\section{PENNSYLVANIA}

General reports: 1 (33), 3 (19), 5 (3), 7 (1), 8 (7 s), $14(1), 18(6), 19$ (21), 20 (16), $21(7 \mathrm{~s}, 18), 22(5)$.

1. Leighton, M. O., Quality of water in the Susquehanna River drainage basin: U. S. Geol. Survey Water-Supply Paper 108, 1904 (out of print) (New York 2). Total solids, incrustants, nonincrustants, and chloride for about 200 surface and ground waters of the area; nitrogen, chloride, total residue, and iron for about 100 surface waters. Part of the area covered by this report is in New York.

2. Lewis, S. J., Quality of water in the upper Ohio River basin and at Erie, Pa.: U. S. Geol. Survey Water-Supply Paper 161, 1906 (out of print). Field assays of waters from streams (100), springs (30), and wells (70).

\section{RHODE ISLAND}

General reports: 1 (2), 3 (2), 4 (6), 6 (13 chloride determinations), 11 (3).

1. Rhode Island State Board of Health Repts. Most of these reports contain sanitary analyses of samples from public supplies and other sources.

\section{SOUTH CAROLINA}

General reports: 1 (6), 2 (9), 3 (6), 8 (2 s), $14(2), 20(2), 21(2 \mathrm{~s}, 1), 22(2)$.

1. South Carolina State Board of Health Repts. Most of the reports contain sanitary analyses of samples from public supplies of the State.

2. South Carolina Agr. Exper. Sta. Fifth Ann. Rept., pp. 21-24, 1893. 22 analyses made at the Experiment Station.

3. South Carolina Agr. Exper. Sta. Seventh Ann. Rept., pp. 16-22, 1895.28 analyses made at the Experiment Station.

4. South Carolina Agr. Exper. Sta. Eighth Ann. Rept., pp. 58-61, 1896.15 complete and 35 partial analyses made at the Experiment Station. 
5. Stephenson, L. W., A deep well at Charleston, S. C., with a report on the mineralogy of the water by Chase Palmer: U. S. Geol. Survey Prof. Paper 90, pp. 69-94, 1915 (out of print). 2 average analyses from general report 8 and 3 analyses of artesian water.

\section{SOUTH DAKOTA}

General reports: $3(3), 10$ (1 s), 20 (1), 21 (13).

1. Shepard, J. H., The artesian waters of South Dakota: South Dakota Agr. Exper. Sta. Bull. 41, 1895. 20 analyses made at the Experiment Station, Bulletin 49, 1896, of the Experiment Station is a continuation of Bulletin 41 and has 11 additional analyses. Bulletin 81,1903 , is substantially a reprint of Bulletins 41 and 49 .

2. Darton, N. H., Preliminary report on artesian waters of a portion of the Dakotas: U.S. Geol. Survey Seventeenth Ann. Rept., pt. 2, pp. 603-694. 1896 (out of print). 22 analyses from miscellaneous sources.

3. Darton, N.H., New developments in well boring and irrigation in eastern South Dakota: U. S. Geol. Survey Eighteenth Ann. Rept., pt. 4 pp. 561616,1898 (\$1.75). 4 analyses (from miscellaneous sources) of waters from South Dakota, 3 from Montana.

4. Todd, J. E., Mineral resources of South Dakota: South Dakota Geol. Survey Bull. 3, pp. 121-129, 1902. 36 analyses (from miscellaneous sources) of spring and well waters.

5. Darton, N. H., and Smith, W. S. T., U. S. Geol. Survey Geol. Atlas, Edgemont folio (No. 108), 1904 (5 cents), 2 analyses obtained from railroad laboratories.

6. Darton, N. H., and O'Harra, C. C., U. S. Geol. Survey Geol. Atlas, Belle Fourche folio (No. 164), 1909 (5 cents). Analyses of water from 3 wells near Orman.

7. Todd, J. E., U. S. Geol. Survey Atlas, Aberdeen-Redfield folio (No. 165), 1909 (out of print). 8 analyses of artesian water from Aberdeen (6 from South Dakota 1).

8. Darton, N. H., Geology and underground waters of South Dakota: U. S. Geol. Survey Water-Supply Paper 227, 1909 (out of print). 7 railroad analyses.

9. Larsen, C., and others, Effects of alkali water on dairy products: South Dakota Agr. Exper. Sta. Bull. 132, pp. 220-254, 1912. Analyses (made at the Experiment Station) of alkali water from 14 different wells, with a discussion of the effects on butter and milk.

10. Darton, N. H., Artesian waters in the vicinity of the Black Hills, S. Dak.: U. S. Geol. Survey Water-Supply Paper 428, 1918 (15 cents). 4 railroad analyses.

11. Sharwood, W. J., Analyses of some rocks and minerals from the Homestake mine, Lead, S. Dak.: Econ. Geology, vol. 6, pp. 729-789, 1911. Analyses (by the author) of waters from the mines (6) and from two creeks (5). Also published in U. S. Geol. Survey Bull. 765, p. 24, 1924.

\section{TENNESSEE}

General reports: 1 (25), 3 (11), 7 (1), 8 (3 s), $12(6), 14(8), 16(6), 20(6), 21$ (3s), $22(2)$.

1. Glenn, L. C., Underground waters of Tennessee and Kentucky west of Tennessee River and of an adjacent area in Illinois: U. S. Geol. Survey Water-Supply Paper 164, 1906 (25 cents). 7 analyses and 5 assays obtained from miscellaneous sources. 3 analyses of waters from Kentucky. 
2. Miser, H. D., Mineral resources of the Waynesboro quadrangle, Tenn.: Tennessee Geol. Survey Bull. 26, 1921. 6 analyses made by Margaret D. Foster, U. S. Geological Survey.

\section{TEXAS}

General reports: 1 (13), 3 (6), 8 (3 s), 10 (1 s), 14 (3), 20 (12), 21 (3 s, 18), $22(3)$.

1. Adriance, Duncan, Tilsen, P. S., and Harrington, H. H., Miscellaneous analyses: Texas Agr. Exper. Sta. Bull. 35, pp. 595-599, 1895. 22 analyses made at the Experiment Station.

2. Hill, R. T., and Vaughan, T. W., Geology of the Edwards Plateau and Rio Grande Plain adjacent to Austin and San Antonio, Tex., with reference to the occurrence of underground waters: U. S. Geol. Survey Eighteenth Ann. Rept., pt. 2, pp. 193-322, 1898 (out of print). 14 analyses from miscellaneous sources.

3. Hill, R. T., Geography and geology of the Black and Grand prairies, Tex., with detailed descriptions of the Cretaceous formations and special reference to artesian waters: U. S. Geol. Survey Twenty-first Ann. Rept., pt. 7, 1901 (out of print). 28 analyses (from miscellaneous sources) of artesian waters.

4. Richardson, G. B., Report of a reconnaissance in trans-Pecos Texas, north of Texas \& Pacific Railroad: Texas Univ. Min. Survey Bull. 9, 1904. 25 analyses (from miscellaneous sources) of mine waters.

5. Slichter, C. S., Observations on the ground waters of Rio Grande valley: U. S. Geol. Survey Water-Supply Paper 141, 1905 (out of print). 10 analyses furnished by A. Courchesne, of El Paso.

6. Taylor, T. U., Underground waters of the Coastal Plain of Texas: U. S. Geol. Survey Water-Supply Paper 190, 1907 (out of print). 16 analyses from miscellaneous sources.

7. Richardson, G. B., U. S. Geol. Survey Geol. Atlas, El Paso folio (No. 166), 1909 (out of print). Analyses of 7 well waters near El Paso by Arthur Goss, New Mexico College of Agriculture, and others.

8. Fraps, G. S., Irrigation waters and alkali soil of Texas: Texas Agr. Exper. Sta. Bull. 130, 1910. 24 analyses (made at the Experiment Station) of surface and ground waters of Pecos Valley. Analyses showing alkali content of about 45 waters.

9. Gordon, C. H., Geology and underground waters of northeastern Texas: U. S. Geol. Survey Water-Supply Paper 276, 1911 (out of print). 29 analyses, 13 made by the U. S. Geological Survey.

10. Gordon, C. H., Geology and underground waters of the Wichita region, north-central Texas: U. S. Geol. Survey Water-Supply Paper 317, 1913 (out of print). 36 analyses, some made by the U. S. Geological Survey.

11. Richardson, G. B., U. S. Geol. Survey Geol. Atlas, Van Horn folio (No. 194), 1914 (25 cents). Analyses for 2 wells near Van Horn, made by the U. S. Geological Survey.

12. Deussen, Alexander, Geology and underground waters of the southeastern part of the Texas Coastal Plain: U. S. Geol. Survey Water-Supply Paper 335,1914 (out of print). 80 analyses from miscellaneous sources, 30 from previous publications.

13. Baker, C. L., Geology and underground waters of the northern Llano Estacado: Texas Bur. Econ. Geology and Technology Bull. 57, 1915. 29 analyses of well waters of Hale County, made at the laboratory of the Bureau of Economic Geology; 12 analyses of well waters from miscellaneous sources, 98 analyses furnished by the Atchison, Topeka \& Santa Fe Railway. 
14. Deussen, Alexander, and Dole, R. B., Ground water in La Salle and McMullen counties Tex.: U. S. Geol. Survey Water-Supply Paper 375, pp. 141-177, 1915 (out of print). 22 analyses and 90 assays of ground waters of the area by W. T. Read, University of Texas.

15. Matson, G. C., and Hopkins, O. B., The Corsicana oil and gas field, Tex.: U. S. Geol. Survey Bull. 661, pp. 211-252, 1918 (out of print). 2 analyses of water from near Corsicana.

16. Schoch, E. P., Chemical analyses of Texas rocks and minerals: Texas Univ. Bull. 1814, 1918. 850 analyses of waters grouped as well waters, surface waters, unclassified waters. A collection of all available analyses for the State. Many of the analyses are from earlier publications.

\section{UTAH}

General reports: 1 (9), 3 (5), 10 (1 s), 14 (8), 17 (9), 20 (6), 21 (23), 22 (13).

1. Cutter, W. P., Value of natural water for crop growth: Utah Agr. Exper. Sta. Bull. 22, 1893.7 analyses made at the Experiment Station.

2. Utah Agr. Exper. Sta. Eighth Ann. Rept., pp. 30-31, 1897. 5 analyses of water from Logan River made at the Experiment Station.

3. Richardson, G. B., Underground water in the valleys of Utah Lake and Jordan River, Utah: U. S. Geol. Survey Water-Supply Paper 157, 1906 (20 cents). Analyses of water from streams, springs, and lakes (21), wells (10), Great Salt Lake (6). Most of these analyses are published elsewhere.

4. Richardson, G: B., Underground water in Sanpete and central Sevier valleys, Utah: U. S. Geol. Survey Water-Supply Paper 199, 1907 (25 cents). 30 field assays made by the author, 1 analysis from Cooper Hot Springs.

5. Lee, W. T., Water resources of Beaver Valley, Utah: U. S. Geol. Survey Water-Supply Paper 217, 1908 (10 cents). 15 analyses, assays of waters from streams (15), springs (16), wells (110).

6. Meinzer, O. E., Ground water in Juab, Millard, and Iron counties, Utah: U. S. Geol. Survey Water-Supply Paper 277, 1911 (25 cents). 19 analyses (from miscellaneous sources) of ground water, 2 of surface water.

7. Carpenter, Everett, Ground water in Boxelder and Tooele counties, Utah: U. S. Geol. Survey Water-Supply Paper 333, 1913 (10 cents). Analyses of water from streams (3), springs (3), Great Salt Lake (8), published in general report 22; field assays (130).

8. Stewart, Robert, and Hirst, C. T., The alkali content of irrigation waters: Utah Agr. Exper. Sta. Bull. 147, 1916. 30 analyses.

9. Groves, J. E., and Hirst, C. T., Composition of the irrigation waters of Utah: Utah Agr. Exper. Sta. Bull. 163, 1918. Analyses (made at the Experiment Station) of waters from streams and lakes (58), springs (8), wells (32), reservoirs (5), drains (8).

\section{VERMONT}

General reports: $1(10), 3(8), 4$ (111 sanitary analyses), 6 (100 chloride determinations), 7 (1), 11 (3), 20 (2), 21 (3).

1. Vermont State Board of Health Repts. Most of the reports contain sanitary analyses of samples from public supplies of the State.

2. Vermont Agr: Exper. Sta. Ann. Repts. Reports from 1889 to 1899 each contain from 13.to 59 partial analyses made at the Experiment Station. 
3. Leighton, M. O., Preliminary report on the pollution of Lake Champlain: U. S. Geol. Survey Water-supply Paper 121, 1905 (20 cents). Analyses of water from Lake Champlain (6), Ticonderoga Creek (2), a number of sanitary analyses.

\section{VIRGINIA}

General reports: 1 (87), $3(38), 7(16), 8$ (3 s), 14 (11), 15 (5), 20 (6), 21 (3 s, 6), $22(6)$.

1. Darton, N. H., U. S. Geol. Survey Geol. Atlas, Norfolk folio (No. 80) 1902 (out of print). Analyses for 2 wells near Norfolk.

2. Sanford, Samuel, Underground water resources of Coastal Plain province: Virginia Geol. Survey Bull. 5, 1913. 275 analyses and field assays (160 assays made by the author).

\section{WASHINGTON}

General reports: 1 (1), $3(1), 10(2 \mathrm{~s}), 14(2), 20(2), 21$ (16 s, 9), 22 (10).

1. Russell, I. C., A geological reconnaissance in central Washington: U. S. Geol. Survey Bull. 108, 1893 (out of print). 12 analyses of water from lakes of the arid region; some of these have been published elsewhere.

2. Byers, H. E., Water resources of Washington: Washington Geol. Survey Ann. Rept., vol. 1, pt. 5, 1901. 42 sanitary analyses of public water supplies, 5 analyses of spring and lake waters.

3. Landes, Henry, Preliminary report on the underground waters of Washington: U. S. Geol. Survey Water-Supply Paper 111, 1905 (10 cents). 12 analyses from miscellaneous sources.

4. VanWinkle, Walton, Quality of the surface waters of Washington; U. S. Geol. Survey Water-Supply Paper 339, 1914 (15 cents). 18 tables containing series of analyses by the author covering periods of about one year for the important rivers of the State.

\section{WEST VIRGINIA}

General reports: 1 (22), 3 (11), 7 (1), 8 (1 s), 13 (2), 14 (1), 17 (3), 18 (17); $19(11), 20(2), 21(1 \mathrm{~s}, 20), 22(1)$.

\section{WISCONSIN}

General reports: 1 (58), 3 (18), 7 (3), 8 (2 s), $20(6), 21$ (2 s, 76), 22 (2).

1. Alden, W. C., U. S. Geol. Survey Geol. Atlas, Milwaukee special folio (No. 140), 1906 (out of print). 9 analyses from miscellaneous sources.

2. Birge, E. A., and Juday, Chancey, The inland lakes of Wisconsin; the dissolved gases of the waters and their biological significance: Wisconsin Geol. and Nat. History Survey Bull. 27, 1914. 225 analyses of water of 19 lakes.

3. Weidman, Samuel, and Schultz, A. R., The undergound and surface water supplies of Wisconsin: Wisconsin Geol. and Nat. History Survey Bull. 35,1915 . 600 analyses of well and spring waters and over 200 analyses of river and lake waters. None of the analyses were made for the report, but they were obtained from various sources- 400 from Chicago, Milwaukee \& St. Paul Railway, 200 from Chicago \& Northwestern Railway, 40 from Dearborn Drug \& Chemical Co., some from water-supply papers of the U. S. Geological Survey. 


\section{WYOMING}

General reports: 1 (7), $3(2), 10(4 \mathrm{~s}), 14(46), 20(2), 21(17), 22(17)$.

1. Gooch, F. A., and Whitfield, J. E., Analyses of the waters of the Yellowstone National Park, with an account of the methods of analysis employed: U. S. Geol. Survey Bull. 47, 1888 (out of print). 44 analyses by the authors. All but 6 of these analyses are in general report 14 .

2. Weed, W. H., Formation of travertine and siliceous sinter by the vegetation of hot springs: U. S. Geol. Survey Ninth Ann. Rept., pp. 613-676, 1889 (\$2). Analyses of several of the waters of Yellowstone Park, many of which are in Wyoming 1.

3. Slosson, E. E., Water analyses: Wyoming Agr. Exper. Sta. Bull. 24, 1895. 35 analyses of samples of spring, well, and irrigation waters made at the Experiment Station.

4. Knight, W. C., A preliminary report on the artesian basins of Wyoming: Wyoming Agr. Exper. Sta. Bull. 45, 1900. 24 analyses made by E. E. Slosson (nearly all in Wyoming 3 ).

5. Knight, W. C., and Slosson, E. E., Alkali lakes and deposits: Wyoming Agr. Exper. Sta. Bull. 49, 1901. Discussion of some of the alkali waters, with analyses made at the Experiment Station.

6. Fisher, C. A., Mineral resources of the Bighorn Basin: U. S. Geol. Survey Bull. 285, pp. 311-315, 1906 (out of print). Analysis (by E. E. Slosson. University of Wyoming) of water from Thermopolis hot springs.

7. Darton, N. H., and Siebenthal, C. E., Geology and mineral resources of the Laramie Basin, Wyo.: U. S. Geol. Survey Bull. 364, 1909 (out of print), 6 analyses by E. E. Slosson, from Wyoming 3, 4. Several analyses of waters and deposits of soda lakes.

8. Darton, N. H., Blackwelder, Eliot, and Siebenthal, C. E., U. S. Geol. Survey Geol. Atlas, Laramie-Sherman folio (No. 173) 1910 (out of print). 3 analyses (from miscellaneous sources) of water from the Union Pacific Soda Lakes, 6 analyses of waters from the Laramie Basin (from Wyoming $3,4)$.

9. Meinzer, O. E., Ground water for irrigation in Lodgepole Valley, Wyo. and Nebr.: U. S. Geol. Survey Water-Supply Paper 425, pp. 37-69, 1919 (out of print) (Nebraska 3). 12 analyses of water from Wyoming and 10 from Nebraska, made by S. C. Dinsmore and others. 
